\title{
Spectroscopic and Density Functional Theory Studies of the Blue-Copper Site in M121SeM and C112SeC Azurin: Cu-Se Versus Cu-S Bonding
}

\author{
Ritimukta Sarangi ${ }^{\dagger}$, Serge I. Gorelsky ${ }^{\dagger}, \ddagger$, Lipika Basumallick ${ }^{\dagger}$, Hee Jung Hwang ${ }^{\perp}$, Russell \\ C. Pratt ${ }^{\dagger}$, T. Daniel P. Stack ${ }^{\dagger}$, Yi Lu $^{\star}{ }^{\star}, \perp$, Keith O. Hodgson ${ }^{\star}, \dagger, \S$, Britt Hedman ${ }^{\star}, \S$, and Edward \\ I. Solomon ${ }^{*},+, \S$ \\ Department of Chemistry, Stanford University, Stanford, California 94305, Stanford Synchrotron \\ Radiation Laboratory, Stanford Linear Accelerator Center, Stanford University, Stanford, California \\ 94309, and Department of Chemistry and Beckman Institute for Advanced Science and Technology, \\ University of Illinois at Urbana-Champaign, Urbana, Illinois 61801
}

\begin{abstract}
S K-edge X-ray absorption, UV-vis absorption, magnetic circular dichroism (MCD), and resonance Raman spectroscopies are used to investigate the electronic structure differences among WT, M121SeM, and C112SeC Pseudomonas aeruginosa (P.a) azurin. A comparison of S K-edge XAS of WT and M121SeM azurin and a Cu${ }^{\mathrm{II}}$-thioether model complex shows that the $38 \% \mathrm{~S}$ character in the ground state wave function of the blue-copper (BC) sites solely reflects the $\mathrm{Cu}-\mathrm{S}_{\mathrm{Cys}}$ bond. Resonance Raman (rR) data on WT and $\mathrm{C} 112 \mathrm{SeC}$ azurin give direct evidence for the kinematic coupling between the $\mathrm{Cu}-\mathrm{S}_{\mathrm{Cys}}$ stretch and the cysteine deformation modes in WT azurin, which leads to multiple features in the rR spectrum of the BC site. The UV-vis absorption and MCD data on WT, $\mathrm{M} 121 \mathrm{SeM}$, and $\mathrm{C} 112 \mathrm{SeC}$ give very similar $C_{0} / D_{0}$ ratios, indicating that the $C$-term MCD intensity mechanism involves $\mathrm{Cu}$-centered spin-orbit coupling (SOC). The spectroscopic data combined with density functional theory (DFT) calculations indicate that $\mathrm{S}_{\mathrm{Cys}}$ and $\mathrm{Se}_{\mathrm{Cys}}$ have similar covalent interactions with $\mathrm{Cu}$ at their respective bond lengths of 2.1 and $2.3 \AA$. This reflects the similar electronegativites of $\mathrm{S}$ and $\mathrm{Se}$ in the thiolate/selenolate ligand fragment and explains the strong spectroscopic similarities between WT and $\mathrm{C} 112 \mathrm{SeC}$ azurin.
\end{abstract}

\section{Introduction}

Azurin belongs to the family of bacterial type I, blue-copper (BC) proteins and is involved in long-range electron transfer. ${ }^{1-6}$ The structure of Pseudomonas aeruginosa (P.a.) azurin is very similar to those of other BC proteins. ${ }^{7-10}$ The active site contains a mononuclear $\mathrm{Cu}$ center that is in a trigonally distorted tetrahedral geometry containing a short $\mathrm{Cu}-\mathrm{S}_{\mathrm{Cys}}$ bond at $\sim 2.1$ $\AA$ and two typical $\mathrm{Cu}-\mathrm{N}_{\mathrm{His}}$ bonds at $\sim 1.95 \AA$. These three ligands lie in the equatorial plane.

\footnotetext{
E-mail: E-mail: yi-lu@uiuc.edu; E-mail: Hodgson@ssrl.slac.stanford.edu; E-mail: Hedman@ssrl.slac.stanford.edu; E-mail: ędward.solomon@stanford.edu.

${ }^{\dagger}$ Stanford University.

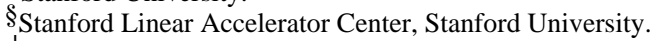

$\stackrel{\perp}{\perp}$ University of Illinois at Urbana-Champaign.

FCurrent address: Center for Catalysis Research and Innovation, Department of Chemistry, University of Ottawa, Ottawa, Ontario K1N $6 \mathrm{~N} 5$, Canada.

Supporting Information Available: The structure of CuL1; overlay of UV-vis absorption and MCD spectra of WT, M121SeM, and C112SeC azurin; geometry-optimized structure and $x y z$ coordinates of $\left[\mathrm{Cu}(\mathrm{tpz})\left(\mathrm{SC}_{6} \mathrm{~F}_{5}\right)\right]$ and $\left[\mathrm{Cu}(\mathrm{tpz})\left(\mathrm{SeC}_{6} \mathrm{~F}_{5}\right)\right]$ and the $\mathrm{LCu}^{+}$and $\mathrm{SC}_{6} \mathrm{~F}_{5}{ }^{-}$interaction energy diagram; and complete ref ${ }^{30}$. This material is available free of charge via the Internet at http://pubs.acs.org.
} 
A weak axial $\mathrm{Cu}-\mathrm{S}_{\mathrm{Met}}$ interaction is present at $\sim 2.9 \AA$. In addition to these four ligands, a weak ionic interaction from an axial carbonyl oxygen of a glycine residue trans to the $S_{\text {Met }}$ ligand is also present in azurins, which is absent in other BC proteins (plastocyanin, amicyanin, etc.). 11

This unusual geometric structure of the $\mathrm{BC}$ sites lends to its unique spectroscopic features. The absorption spectrum is dominated by an intense $\mathrm{S}_{\mathrm{Cys}} \mathrm{p} \pi \rightarrow \mathrm{Cu}$ charge-transfer transition at $\sim 600 \mathrm{~nm}\left(\varepsilon=5000 \mathrm{~cm}^{-1} \mathrm{M}^{-1}\right)$, which imparts the brilliant blue color to the protein. ${ }^{4,12}$ The electron paramagnetic resonance (EPR) spectrum has a much lower hyperfine coupling value $\left(A_{\|} \leq 80 \times 10^{-4} \mathrm{~cm}^{-1}\right)$ relative to normal Cu sites $\left(A_{\|} \approx 160 \times 10^{-4}\right.$ to $\left.200 \times 10^{-4} \mathrm{~cm}^{-1}\right) .{ }^{12}$ These unusual spectral features of the $\mathrm{BC}$ site derive from a highly covalent $\mathrm{Cu}-\mathrm{S}_{\mathrm{Cys}}$ bond resulting from the strong interaction between the $\mathrm{Cu} 3 \mathrm{~d}_{x^{2}-y^{2}}$ acceptor orbital and the $\mathrm{S} 3 \mathrm{p} \pi$ donor orbital. Resonance Raman ( $\mathrm{rR}$ ) data have indicated a high $\mathrm{Cu}-\mathrm{S}$ stretching frequency of $\sim 400 \mathrm{~cm}^{-1}$ supporting a strong $\mathrm{Cu}-\mathrm{S}_{\mathrm{Cys}}$ bond. ${ }^{13}$ A direct estimate of the $\mathrm{Cu}-\mathrm{S}_{\mathrm{Cys}}$ covalent interaction (amount of $\mathrm{S}$ character in the ground state wave-function) has been obtained from S K-edge X-ray absorption spectroscopy (XAS). ${ }^{14}$ The high intensity of the XAS pre-edge transition at $\sim 2469 \mathrm{eV}$ indicates that $\sim 38 \% \mathrm{~S}$ character is mixed into the $\mathrm{Cu} 3 \mathrm{~d}_{x^{2}-y^{2}}$ orbital in the ground state. This strong anisotropic covalency of the $\mathrm{Cu}-\mathrm{S}_{\mathrm{Cys}}$ bond activates the bluecopper site for its biological function of long-range, rapid, directional electron transfer. ${ }^{10,12 \text {, }}$ $15-17$

Recently, the expressed protein ligation (EPL) technique has been developed that allows facile incorporation of natural and unnatural amino acids into proteins. ${ }^{18,19} \mathrm{Lu}$ et al. have recently incorporated $\mathrm{Se}_{\mathrm{Met}}$ (M121SeM mutant) and $\mathrm{S}_{\mathrm{Cys}}(\mathrm{C} 112 \mathrm{SeC}$ mutant) into the active site of P.a. azurin. ${ }^{20,21}$ The UV-vis absorption, EPR, and extended X-ray absorption fine structure (EXAFS) spectra of these mutants have been measured and compared to that of WT P.a. azurin. 22 These spectroscopic data were very similar for M121SeM and WT, indicating similar geometric and electronic structures of the two proteins. This was consistent with previous results, which showed that the axial $\mathrm{S}_{\text {Met }}$ ligand does not significantly contribute to the groundstate wave-function. ${ }^{4}$ EXAFS studies on $\mathrm{C} 112 \mathrm{SeC}$ indicated a $\mathrm{Cu}-\mathrm{Se}_{\mathrm{Cys}}$ bond length of $\sim 2.3$ $\AA$ (relative to $\sim 2.14 \AA$ for the $\mathrm{Cu}-\mathrm{S}_{\mathrm{Cys}}$ in WT P.a. azurin), consistent with an increase in the size of Se relative to $S .^{22}$ EPR studies showed that the spin-orbit coupling (SOC) of Se had a large effect on the spectrum but were inconclusive in determining the change in bond strength between $\mathrm{Cu}-\mathrm{S}_{\mathrm{Cys}}$ and $\mathrm{Cu}-\mathrm{Se}_{\mathrm{Cys}}$.

In this study, a combination of UV-vis absorption, magnetic circular dichroism (MCD), rR, S K-edge XAS, and density functional theory (DFT) calculations are applied to WT, M121SeM, and $\mathrm{C} 112 \mathrm{SeC}$ P.a. azurin to quantitatively probe the electronic structure differences due to replacement of $\mathrm{S}_{\mathrm{Met}}$ and $\mathrm{S}_{\mathrm{Cys}}$ with $\mathrm{Se}_{\mathrm{Met}}$ and $\mathrm{Se} \mathrm{C}_{\mathrm{Cys}}$, respectively. S K-edge data on M121SeM and WT, combined with data on a $\mathrm{Cu}^{\mathrm{II}}$-thioether complex, help uncouple the contribution of $\mathrm{S}_{\mathrm{Met}}$ and $\mathrm{S}_{\mathrm{Cys}}$ to the ground-state wave-function and show that the $\mathrm{S}$ K-pre-edge intensity at $\sim 2469 \mathrm{eV}$ solely reflects the $\mathrm{Cu}-\mathrm{S}_{\mathrm{Cys}}$ bond. $\mathrm{rR}$ data on $\mathrm{C} 112 \mathrm{SeC}$ and $\mathrm{WT}$ have been used to experimentally probe and compare the $\mathrm{Cu}-\mathrm{Se}_{\mathrm{Cys}}$ and $\mathrm{Cu}-\mathrm{S}$ Cys bonds. $\mathrm{EPR}$ and $\mathrm{MCD}$ data are both affected by SOC. In this study, the effect of ligand SOC $\left(\mathrm{Se}=1690 \mathrm{~cm}^{-1}, \mathrm{~S}=382\right.$ $\mathrm{cm}^{-1}$ ) on MCD data is investigated. The very similar $C_{0} / D_{0}$ ratios in WT and C112SeC P.a. azurin indicate that only the SOC of the $\mathrm{Cu}$ center $\left(828 \mathrm{~cm}^{-1}\right)$ determines the MCD intensity. Finally, these results are coupled with DFT calculations to determine that the $\mathrm{Cu}-\mathrm{S}_{\mathrm{Cys}}$ and $\mathrm{Cu}-$ $\mathrm{Se}_{\mathrm{Cys}}$ bonds are, in fact, very similar and to elucidate the factors affecting the nature of metalSe versus metal-S bonding. 


\section{Experimental Section}

\subsection{Sample Preparation}

WT azurin samples were purified from Pseudomonas aeruginosa (P.a.) as previously described. ${ }^{23,24}$ The $\mathrm{C} 112 \mathrm{SeC}$ and M121SeM proteins were prepared using the expressed protein ligation (EPL) method as previously described. ${ }^{20,22}$ All samples were purified by anion-exchange chromatography, on a POROS 20HQ anion-exchange resin with a BioCad Sprint high-performance liquid chromatograph (HPLC) (Per-Septive Biosystems, Farmingham, MA) or an AKTA basic (GE Healthcare, Piscataway, NJ) system after copper incorporation liquid chromatography-mass spectroscopy (LC-MS) mass spectral data were collected for WT and M121SeM azurin, and show a single peak in the mass spectrum corresponding to the weight of the full-length protein (wild-type or variant) with no evidence of residual contamination from other proteins or synthetic peptides in the WT and $4 \%$ contamination from unligated apoprotein. The degree of copper incorporation was assessed by comparison of the $280 \mathrm{~nm}$ and the 625 or $677 \mathrm{~nm}$ peak in the electronic absorption spectrum and from EPR spin quantitation. WT and M121SeM mutant azurin were prepared in NH4OAc buffer at $\mathrm{pH} 5.1$ while $\mathrm{C} 112 \mathrm{SeC}$ was prepared in Tris $\mathrm{HCl}$ buffer at $\mathrm{pH} 8.0$ owing to the increased stability of this variant at elevated $\mathrm{pH}$. All protein solutions were $\sim 2.5 \mathrm{mM}$. Samples were transferred into MCD and S K-edge XAS cells for spectroscopic characterization and kept under liquid $\mathrm{N}_{2}$ conditions until data collection.

\subsection{S K-edge X-ray Absorption}

S K-edge spectra were measured using the SSRL 54-pole wiggler beamline 6-2 in high magnetic field mode of $10 \mathrm{kG}$ with a Ni-coated harmonic rejection mirror and a fully tuned $\mathrm{Si}$ (111) double-crystal monochromator. Details of the optimization of this beam line for lowenergy fluorescence measurements and the experimental setup have been described previously. $25,26 \mathrm{~S}$ K-edge measurements were made at $\sim 4^{\circ} \mathrm{C}$. Protein samples were pre-equilibrated in a water-saturated $\mathrm{He}$ atmosphere for $\sim 0.5-1 \mathrm{~h}$ to minimize bubble formation in the sample cell. Protein solutions were loaded via syringe into a Pt-coated Al block sample holder with a 6.35 $\mu \mathrm{m}$ thick polypropylene window. The data were measured as fluorescence excitation spectra utilizing an ionization chamber as a fluorescence detector. All protein samples were monitored for potential effects of photoreduction throughout the course of data collection. The partially beam-reduced WT, C112SeC, and M121SeM samples were oxidized with a 10-fold excess of $\mathrm{K}_{3}\left[\mathrm{Fe}(\mathrm{CN})_{6}\right]$, which allowed 8-, 4-, and 8-scan averages, respectively, to be obtained with no further indication of photoreduction. The energy was calibrated from $\mathrm{S}$ K-edge spectra of $\mathrm{Na}_{2} \mathrm{~S}_{2} \mathrm{O}_{3} \cdot 5 \mathrm{H}_{2} \mathrm{O}$, run at intervals between sample scans. Data normalization was performed as described in earlier publications. ${ }^{26}$ The area under the pre-edge peak was quantified by fitting the data using EDG_FIT. ${ }^{27}$ The pre-edge and rising-edge features were modeled with pseudoVoigt line-shapes with a fixed 1:1 Lorentzian/Gaussian ratio. The reported intensity and halfwidth values are based on averages over simultaneous fits that accurately modeled the data and their second derivative. Normalization procedures introduce $\sim 3 \%$ error in the value of the integrated area under the pre-edge peak.

\subsection{UV-Vis Absorption and Magnetic Circular Dichroism}

Absorption spectra at temperatures between 5 and $300 \mathrm{~K}$ were measured using a computerinterfaced Cary-500 spectrophotometer modified to accommodate a Janis Research Super Vari-Temp cryogenic dewar mounted in the light path. Low-temperature magnetic circular dichroism spectra were obtained using two Jasco spectropolarimeters. Each is equipped with a modified sample compartment to accommodate focusing optics and an Oxford Instruments SM4000-7T superconducting magnet/cryostat. This arrangement allows data collection at temperatures ranging from 1.6 to $290 \mathrm{~K}$ and fields up to $7 \mathrm{~T}$. ${ }^{28}$ A Jasco $\mathrm{J} 810$ spectropolarimeter operating with a S-20 photomultiplier tube was used for the ultraviolet and visible spectral 
regions. A Jasco J200 spectropolarimeter operating with a liquid nitrogen cooled InSb detector was used for the near-infrared region. Depolarization of the light by the MCD samples was monitored by the differences in the circular dichroism spectra of nickel (+)-tartarate placed before and after the sample. In all cases, the depolarization was less than 5\%. ${ }^{29} \mathrm{MCD}$ samples were run in cells fitted with quartz disks and a $0.3 \mathrm{~cm}$ rubber gasket spacer. Simultaneous Gaussian fitting of the absorption and MCD spectra was performed using the commercially available Peak-Fit program.

\subsection{Resonance Raman}

Resonance Raman (rR) spectra were collected with a Princeton Instruments ST-135 backilluminated charge-coupled device (CCD) detector on a Spex $1877 \mathrm{CP}$ triple monochromator with 1200, 1800, and 2400 grooves/mm holographic gratings. Continuous wave coherent $\mathrm{Kr}$ ion (Innova90C-K) and an Ar ion (Sabre-25/7) visible and UV laser lines were used as variable excitation sources. A polarization scrambler was used between the sample and the spectrometer. The Raman energy was calibrated with $\mathrm{Na}_{2} \mathrm{SO}_{4}$. Frequencies are accurate to within $<2 \mathrm{~cm}^{-1}$. Samples were loaded in $4 \mathrm{~mm}$ NMR tubes and stored in liquid nitrogen.

\subsection{Computational Details}

Density functional theory (DFT) calculations were performed on a 141-atom molecular model of the blue-copper site derived from the $1.5 \AA$ A resolution structure of oxidized P.a. azurin (PDB code $1 \mathrm{JZF}$ ). This model for the azurin was optimized, keeping the backbone $\mathrm{C}$ and $\mathrm{N}$ atom coordinates constrained to their crystallographic positions. To model the M121SeM and $\mathrm{C} 112 \mathrm{SeC}$ azurin mutants, the WT active site was modified by replacing the corresponding $\mathrm{S}$ atom by Se and the resulting structures were reoptimized, keeping the backbone atoms constrained. In addition, the DFT calculations have been performed on the $\mathrm{BC}$ model complexes $\left[\mathrm{Cu}(\mathrm{tpz})\left(\mathrm{XC}_{6} \mathrm{~F}_{5}\right)\right]$, where $\mathrm{X}=\mathrm{S}$ and $\mathrm{Se}$ and tpz is the tris(1-pyrazolyl)hydroborate ligand.

Spin-unrestricted DFT calculations were performed using the Gaussian 03 program ${ }^{30}$ (Revision C.02) with the B3LYP exchange-correlation functional, ${ }^{31}$ which provides a reasonable orbital description of the copper sites in the model complexes. The triple- $\zeta$ TZVP basis set ${ }^{32}$ on the $\mathrm{Cu}, \mathrm{S}$, and $\mathrm{Se}$ atoms and the double- $\zeta 6-31 \mathrm{G}^{*}$ basis set ${ }^{33-35}$ on the $\mathrm{O}, \mathrm{N}$, $\mathrm{C}$, and $\mathrm{H}$ atoms were used. Extending the basis set to TZVP for the $\mathrm{O}, \mathrm{N}, \mathrm{C}$, and $\mathrm{H}$ atoms did not change the calculated spin density distribution in the blue-copper site of azurin. For the $\left[\mathrm{Cu}(\mathrm{tpz})\left(\mathrm{XC}_{6} \mathrm{~F}_{5}\right)\right]$ complexes, the $6-311+\mathrm{G}^{*}$ basis set was used for the geometry optimization. Harmonic frequency calculations were performed on the $\left[\mathrm{Cu}(\mathrm{tpz})\left(\mathrm{XC}_{6} \mathrm{~F}_{5}\right)\right]$ model to obtain the $\mathrm{Cu}-\mathrm{X}$ normal modes and the nuclear mass effect (by changing $M_{\mathrm{Se}}$ of 80 to 32 a.u. $\left(M_{\mathrm{S}}\right)$ ) on their frequencies. Then, the single-point calculations at B3LYP/TZVP level were used to evaluate bonding between the metal fragment and the $\mathrm{XC}_{6} \mathrm{~F}_{5}{ }^{-}$ligand. Tight self-consistent field (SCF) convergence criteria $\left(10^{-8}\right.$ a.u.) were used for all calculations. Wave-function stability calculations were performed (using the STABLE keyword) on all optimized wavefunctions to confirm that they corresponded to the true ground state.

Molecular orbital (MO) compositions were calculated with the AOMix program ${ }^{36,37}$ using the Mulliken population analysis (MPA). ${ }^{38-41}$ Atomic charges and spin densities were calculated using natural population analysis methods (NPA), ${ }^{42}$ as implemented in Gaussian 03 , and the Mayer bond orders, ${ }^{43-46}$ as implemented in AOMix-L.

Force constants were calculated by fitting the $\mathrm{Cu}-\mathrm{X}_{\text {thiolate }}$ potential surface to the polynomial function: 


$$
E=E_{0}+\frac{1}{2} k\left(d-d_{0}\right)^{2}+k_{\mathrm{a}}\left(d-d_{0}\right)^{3}
$$

Time-dependent density functional theory (TD-DFT) was used to calculate the energies and intensities of the 35 lowest-energy spin-allowed electronic transitions. These were transformed with the SWizard program into simulated spectra as described before, using Gaussian functions with half-widths of $3000 \mathrm{~cm}^{-1}$.

The time-dependent density functional theory (TD-DFT) framework implemented in $\mathrm{ORCA}^{47}$ was used to compute $\mathrm{Cu} \mathrm{K}$ pre-edge (Cu $1 \mathrm{~s} \rightarrow \psi^{*}{ }_{\beta}$-LUMO) and $\mathrm{S}$ K pre-edge (S $1 \mathrm{~s}$ $\rightarrow \psi^{*} \beta$-LUMO) transition energies. Single-point calculations were performed on CuL1 and $\left[(\mathrm{Im})_{2} \mathrm{Cu}(\mathrm{SMe})(\mathrm{SMe})_{2}\right]^{+}$(modified from the crystal structure of P.a. azurin) in Gaussian03 using the BP86 $6^{31,48-50}$ with the 6-311G*51-53 basis set on $\mathrm{Cu}$ and $\mathrm{S}$ and $6-31 \mathrm{G}^{*}$ basis set $^{33-35}$ on the rest of the atoms. Single-point ground-state DFT calculations with the BP86 functional were performed using the geometry-optimized coordinates obtained from Gaussian03. The Ahlrichs' triple- $\xi$ valence basis TZVP 32 was used on all atoms. The DFT calculations were repeated on the geometry-optimized structures of $\mathrm{CuL1}$ (with the tertiary butyl groups replaced by $\mathrm{H}$ atoms) and the azurin model, and similar energy shifts were obtained.

\section{Results and Analysis}

\subsection{S K-edge XAS}

The renormalized ${ }^{54} \mathrm{~S}$ K-edge X-ray absorption spectra of WT, C112SeC, and M121SeM mutants of P.a. azurin are shown in Figure 1. The WT and M121SeM spectra have a low-energy transition at $\sim 2469 \mathrm{eV}$, which is absent in the $\mathrm{C} 112 \mathrm{SeC}$ azurin spectrum. This pre-edge feature, which appears below the onset of the sharp-edge transition, is associated with the Cys $\mathrm{S} 1 \mathrm{~s} \rightarrow$ $\psi^{*} \beta$-LUMO transition (the lowest unoccupied $\beta$-spin molecular orbital in a spin-unrestricted description). ${ }^{26,55-57}$ Because of the localized nature of the $\mathrm{S} 1 \mathrm{~s}$ orbital, this transition is observed if $\psi^{*}{ }_{\beta \text {-LUMO }}$ contains significant S $3 \mathrm{p}$ character and gains intensity as the $\mathrm{S} 3 \mathrm{p}$ character in this orbital increases. Thus, the pre-edge intensity is proportional to the $\mathrm{S} 1 \mathrm{~s} \rightarrow$ $3 \mathrm{p}$ transition intensity weighted by $\mathrm{S}_{\text {thiolate }}$ contribution to $\psi^{*} \beta$-LUMO. Integrating the area under the pre-edge peak and using the area obtained from the S K-pre-edge transition of plastocyanin as a reference (well-characterized from various spectroscopies with $38 \% \mathrm{~S}$ character in $\psi^{*} \beta$-LUMO), ${ }^{14}$ a direct estimate of the $\mathrm{Cu} 3 \mathrm{~d}-\mathrm{S} 3 \mathrm{p} \pi$ contribution to $\mathrm{Cu}-\mathrm{S}$ bond covalency can be obtained. Table 1 gives the $\% \mathrm{~S}$ character and the energies of the pre-edge and edge features of WT, $\mathrm{C} 112 \mathrm{SeC}$, and $\mathrm{M} 121 \mathrm{SeM}$ azurin. The pre-edge energy reflects a combination of $Q_{\mathrm{mol}}^{\mathrm{Cu}}$ (charge on $\mathrm{Cu}$ in the molecule), $Q_{\mathrm{mol}}^{\mathrm{S}}$ (charge on $\mathrm{S}$ in the molecule), and the ligand field (LF) felt by the central Cu atom. ${ }^{56}$ The pre-edge occurs at 2469 and 2468.9 $\mathrm{eV}$ in WT and M121SeM azurin, respectively. The similarity in the pre-edge energy positions in WT and M121SeM indicates comparable $Q_{\mathrm{mol}}^{\mathrm{S}}, Q_{\mathrm{mol}}^{\mathrm{Cu}}$, and Cu LFs in these two proteins. The edge energy reflects the $Q_{\mathrm{mol}}^{\mathrm{S}}$ in the molecule. However, azurin contains two cysteines and five methionines (in addition to the coordinating Cys and Met residues), which are not bound to the $\mathrm{Cu}$ center but contribute to the energy and the total intensity of the $\mathrm{S} 1 \mathrm{~s} \rightarrow 3$ p edge transition. 7 This precludes an estimation of $Q_{\mathrm{mol}}^{\mathrm{S}}$ from the edge energy position.

It has been shown that the ground state $\mathrm{S}$ character in blue-copper proteins predominantly comes from the covalent $\mathrm{Cu}-\mathrm{S}_{\mathrm{Cys}}$ interaction. ${ }^{4}$ This is consistent with the absence of the preedge feature in $\mathrm{C} 112 \mathrm{SeC}$ in which $\mathrm{S}_{\mathrm{Cys}}$ has been replaced by $\mathrm{Se}_{\mathrm{Cys}}{ }^{58}$ In WT and M121SeM azurin, the $\% \mathrm{~S}$ character in the $\psi^{*}$ LUMO is $40 \pm 3 \%$ and $37.5 \pm 3 \%$, respectively (Table 1 ), 
indicating a small decrease in S character in M121SeM azurin. ${ }^{59}$ Although the $\mathrm{S}$ characters in the ground states of WT and M121SeM are quite similar (within error), in principle, a small decrease could reflect loss of a small contribution of the $S_{\text {Met }}$ to the pre-edge intensity. Alternatively, the larger size of Se relative to $\mathrm{S}$ can potentially increase the charge donation from $\mathrm{Se}_{\mathrm{Met}}$ to $\mathrm{Cu}$ and consequently decrease the $\mathrm{S}_{\mathrm{Cys}}$ contribution to $\psi^{*} \mathrm{~S}_{\mathrm{Cys}}$ bond $\beta$-LUMO. EXAFS studies have shown that the $\mathrm{Cu}$-distance does, in fact, increase from 2.14 to $2.18 \AA$ on going from WT to M121SeM azurin. ${ }^{20}$ In order to evaluate the contribution of the $\mathrm{S}_{\mathrm{Met}}$ to $\psi^{*} \beta$-LUMO, the $\mathrm{S}$ K-edge spectrum of a Cu- $\mathrm{S}_{\text {thioether }}$ model complex, $\mathrm{CuL} 1$ (where $\mathrm{H}_{2} \mathrm{~L} 1=$ 2,6- bis[S-(3,5-di-tert-butyl-2-hydroxyphenyl)sulfanylmethyl]pyridine), ${ }^{60}$ was obtained (see Supporting Information, Figure S1). The structure of CuL1 is five-coordinate with two $\mathrm{Cu}-$ $\mathrm{S}_{\text {thioether }}$ bond lengths of $2.4 \AA$. DFT calculations on CuL1 give a $\psi^{*} \beta$-LUMO with $\sim 13 \%$

$\mathrm{S}_{\text {thioether }}$ character, therefore predicting a S K-pre-edge feature with significant intensity. Figure 2 shows the $\mathrm{S}$ K-edge data of $\mathrm{CuL1}$, which exhibits a pre-edge transition at $2472.1 \mathrm{eV}$. Figure 2 also compares the normalized S K-edge spectra of WT azurin with that of CuL1. The pre-edge feature due to the $\mathrm{Cu} 3 \mathrm{~d}-\mathrm{S}_{\text {thiolate }}$ covalent interaction in WT azurin occurs at 2469.0 $\mathrm{eV}$, while that due to the $\mathrm{Cu} 3 \mathrm{~d}-\mathrm{S}_{\text {thioether }}$ covalent interaction in CuL1 occurs $3.1 \mathrm{eV}$ to higher energy at $2472.1 \mathrm{eV}$. The $\mathrm{S} \mathrm{K}$ pre-edge energy position shifts to higher energy with an increase in $Q_{\mathrm{mol}}^{\mathrm{S}}$ and $\mathrm{LF}$ and to lower energy with an increase in $Q_{\mathrm{mol}}^{\mathrm{Cu}}$. In order to estimate the differences in $Q_{\mathrm{mol}}^{\mathrm{Cu}}, Q_{\mathrm{mol}}^{\mathrm{S}}$, and ligand field, DFT and $\mathrm{Cu} 1 \mathrm{~s} \rightarrow \psi^{*} \beta$-LUMO and $\mathrm{S} 1 \mathrm{~s} \rightarrow \psi^{*} \beta$-LUMO TD-DFT calculations were performed on $\mathrm{CuL} 1$ and the azurin model. Calculations show that the energies of S K pre-edge ( $\mathrm{S} 1 \mathrm{~s} \rightarrow \psi^{*}{ }_{\beta-\mathrm{LUMO}}$ ) and $\mathrm{Cu} \mathrm{K}$ pre-edge (Cu 1s $\rightarrow \psi^{*}{ }_{\beta \text {-LUMO }}$ ) transitions are, respectively, 2.1 and $0.7 \mathrm{eV}$ higher in $\mathrm{CuL} 1$ than in the azurin model (Figure S2). It has been previously shown that the $1 \mathrm{~s} \rightarrow 3 \mathrm{~d}$ transition energy at the $\mathrm{Cu}$ K-edge dominantly reflects the ligand-field strength felt by the $\mathrm{Cu}$ center. Thus, an $\sim 1.4 \mathrm{eV}$ increase in the $\mathrm{S} \mathrm{K}$-pre-edge energy in $\mathrm{CuL} 1$ is due to a combination of $Q_{\mathrm{mol}}^{\mathrm{Cu}}$ and $Q_{\mathrm{mol}}^{\mathrm{S}}$. DFT calculations show that $Q_{\mathrm{mol}}^{\mathrm{Cu}}$ is lower in the azurin active site compared to that in $\mathrm{CuL} 1$. This is consistent with a very covalent $\mathrm{Cu}-$ $\mathrm{S}_{\text {thiolate }}$ in azurin, which leads to only $41 \% \mathrm{Cu}$ character in the ground state (Cu L-edge XAS) 61 compared to the significantly weaker $\mathrm{Cu}-\mathrm{S}_{\text {thioether }}$ bonds in $\mathrm{CuL1}$, which results in $\sim 70 \%$ $\mathrm{Cu}$ character in the ground state (DFT calculations). ${ }^{60}$ Since an increase in $Q_{\mathrm{mol}}^{\mathrm{Cu}}$ decreases the pre-edge energy position, the increase in the pre-edge energy, due to changes in $Q_{\mathrm{mol}}^{\mathrm{S}}$ on going from a Cu- $\mathrm{S}_{\text {thiolate }}$ system to a $\mathrm{Cu}-\mathrm{S}_{\text {thioether }}$ system, is expected to be significantly higher than $\sim 1.4 \mathrm{eV}$. This is consistent with the fact that the rising-edge of CysNa (Na salt of cysteine

thiolate) is $\sim 1.8 \mathrm{eV}$ lower in energy than that of methionine, reflecting an increase in $Q_{\mathrm{mol}}^{\mathrm{S}}$ in methionine. ${ }^{62,63}$ Thus, any contribution of the $S_{\text {thioether }}$ to the ground-state wave-function in azurin would be to higher energy than the pre-edge transition at $\sim 2470 \mathrm{eV}$. Since no corresponding feature is observed to higher energy, the results confirm that $\mathrm{Cu}-\mathrm{S}_{\mathrm{Met}}$ covalent interaction is very small in azurin64 and give experimental evidence for the fact that the preedge intensity is a direct reflection of the $\mathrm{Cu}-\mathrm{S}_{\text {thiolate }}$ covalency in azurin, and the similar preedge intensities in WT and M121SeM reflect very similar covalent interactions. ${ }^{65}$

\subsection{UV-Vis Absorption and Magnetic Circular Dichroism}

Low-temperature absorption and MCD spectra between 5000 and $30000 \mathrm{~cm}^{-1}$ for WT, M121SeM, and C112SeC azurin are presented in Figure 3. The transition energies and $\varepsilon$ and $\Delta \varepsilon$ values obtained from the simultaneous Gaussian fits are presented in Table 2. The absorption and MCD spectra of azurin have been shown to be similar to plastocyanin, and hence, the following analysis is based on the band assignments in plastocyanin. 4,5 The Gaussian resolution of the absorption and MCD data require eight bands to adequately fit the spectra for each protein and have been included using dashed lines. For all three proteins, bands 1-4 in the high-energy region ( $\left.>16000 \mathrm{~cm}^{-1}\right)$ have high absorption intensity and low MCD intensity. The low-energy region (5000-15 $000 \mathrm{~cm}^{-1}$ ) also consists of four bands (only two are observed 
in the absorption spectra) that show low absorption intensity and high MCD intensity. On the basis of the spectral assignments of plastocyanin, 12,66 the four high-energy bands in azurin, M121SeM, and C112SeC are assigned as ligand-to-metal charge-transfer transitions, while the four lower energy bands are assigned to metal-based $d \rightarrow d$ (LF) transitions. ${ }^{5,67,68}$ The bluecopper site has been found to have a relatively small splitting of the $\mathrm{d}_{x z, y z}$ orbitals. ${ }^{69}$ This closeto-degenerate orbital set exhibits a pseudo- $A$ term with the higher-energy transition having a negative sign (band 5) and the lower-energy transition (band 6) having a positive sign. ${ }^{66}$ Band 7 is assigned to the $\mathrm{d}_{x y} \rightarrow \mathrm{d}_{x^{2}-y^{2}}$ transition and at lowest energy, band 8 , is assigned to the $\mathrm{d}_{z}{ }^{2} \rightarrow \mathrm{d}_{x^{2}-y^{2}}$ transition. The charge-transfer region $\left(14000-25000 \mathrm{~cm}^{-1}\right)$ is dominated by an intense transition, band 4, which is responsible for the blue color of these proteins. In analogy to other well-characterized blue-copper proteins, this band involves the strong $\mathrm{Cu} 3 \mathrm{~d}-\mathrm{S} \mathrm{p} \pi$ interaction and is assigned as the $\mathrm{S}_{\text {thiolate }} 3 \mathrm{p} \pi \rightarrow \mathrm{Cu} \mathrm{d}_{x^{2}-y^{2}}$ charge-transfer (CT) transition. To higher energy, a low-intensity transition is observed (band 3), which is assigned to the S $3 \mathrm{p}$ pseudo $\sigma \rightarrow \mathrm{d}_{x^{2}-y^{2}}$ charge-transfer transition. The intense $\pi$, weak $\sigma \mathrm{CT}$ intensity inverted from that observed for normal $\mathrm{Cu}$ complexes and was attributed to the fact that the lobes of the halfoccupied $\mathrm{Cu} 3 \mathrm{~d}_{x^{2}-y^{2}}$ orbital bisect the $\mathrm{S}-\mathrm{Cu}$ bond. The weak transitions band 1 and band 2 have been assigned to transitions from His $(\pi)$ and $\mathrm{S}_{\mathrm{Met}}$ to $\mathrm{Cu} \mathrm{d}_{x}{ }^{2} y^{2} \mathrm{CT}$ transitions. The intensities in the absorption spectra, ${ }^{66}$ ENDOR studies, ${ }^{70}$ and DFT calculations $4,5,71$ have shown that the two His $(\pi)$ and $\mathrm{S}_{\mathrm{Met}}$ valence orbital overlaps with the half-occupied $\mathrm{Cu}$ $\mathrm{d}_{x^{2}-y^{2}}$ orbital are low.

3.2.1. Comparison of WT and M121SeM Azurin-The absorption and MCD spectra of WT and M121SeM azurin are very similar with only small quantitative differences (Table 2). The ligand-field bands are lower in energy in M121MSe compared to WT by an average value of $\sim 170 \mathrm{~cm}^{-1}$. This difference is very small, indicating similar ligand-field strengths at the $\mathrm{Cu}$ center in both systems. Band 8, which is assigned as the $\mathrm{d}_{z^{2}} \rightarrow \psi^{*} \beta$-LUMO $\mathrm{d} \rightarrow \mathrm{d}$ transition, occurs at $5430 \mathrm{~cm}^{-1}$ and $5420 \mathrm{~cm}^{-1}$ in WT and M121SeM, respectively. The energy of the $\mathrm{d}_{z}{ }^{2}$ orbital is tuned by two factors, the strength of the axial S/Se $\mathrm{Met}-\mathrm{Cu}$ interaction and the extent of $\mathrm{Cu} 4 \mathrm{~s}$ mixing into the $\mathrm{d}_{z} 2$ orbital. $\mathrm{Cu} 4 \mathrm{~s}$ mixing with the $\mathrm{d}_{z} 2$ orbital decreases while the axial donor interaction increases the energy of the $\mathrm{d}_{z} 2$ orbital. As the energy of band 8 is the same in WT and M121SeM, replacement of the axial $S_{M e t}$ by $S_{\text {Met }}$ does not significantly perturb the axial interaction. The intense charge-transfer transition, band 4, occurs at 15900 $\mathrm{cm}^{-1}\left(\varepsilon=5070 \mathrm{M}^{-1} \mathrm{~cm}^{-1}\right)$ for WT and is slightly lower in energy and intensity for M121SeM at $15800 \mathrm{~cm}^{-1}\left(\varepsilon=4700 \mathrm{M}^{-1} \mathrm{~cm}^{-1}\right)$. This is consistent with the small decrease in the $\mathrm{S}$ character in $\psi^{*}$ LUMO of M121SeM relative to WT observed from S K-edge XAS (vide supra) and supports the above analysis that the decrease in pre-edge intensity is due to weakening of the $\mathrm{Cu}-\mathrm{S}_{\mathrm{Cys}}$ bond. Band 1, which is assigned as the $\mathrm{S}_{\mathrm{Met}} \rightarrow \mathrm{Cu}$ CT transition, is very similar in WT and M121SeM. This indicates that, going from $\mathrm{S}_{\mathrm{Met}}$ to $\mathrm{Se}_{\mathrm{Met}}$, the $\mathrm{Cu}-\mathrm{S} / \mathrm{Se}$ axial donor interaction is not significantly perturbed. This is consistent with the strong similarity between the $\mathrm{Cu}-\mathrm{S}_{\mathrm{Cys}} / \mathrm{Se}_{\mathrm{Cys}}$ interaction described below.

3.2.2. Comparison of WT and C112SeC Azurin-A comparison of the absorption and MCD spectra of C112SeC with WT and M121SeM azurin is shown in Figure 3C (see also Figure S3 in Supporting Information) and Table 2. Gaussian fits to the LF region indicate that bands 5-8 are lower in energy by an average of only $\sim 200 \mathrm{~cm}^{-1}$ in $\mathrm{C} 112 \mathrm{SeC}$ relative to WT. The energy of band 8 is comparable for WT $\left(5430 \mathrm{~cm}^{-1}\right)$ and $\mathrm{C} 112 \mathrm{SeC}\left(5400 \mathrm{~cm}^{-1}\right)$, indicating similar axial interaction between the $S_{\text {Met }}$ and the $\mathrm{Cu} \mathrm{d} z^{2}$ orbitals. This similarity in the $d-d$ transition energy indicates comparable LF strengths in the two proteins. In the charge-transfer region, the intense blue band, band 4 , is shifted to lower energy by $1700 \mathrm{~cm}^{-1}$ in $\mathrm{C} 112 \mathrm{SeC}$ relative to WT and results in the overlap of band 4 and band 5 in the absorption and MCD spectra (Figure 3). While the DFT calculations in Section 4.2 show that the electronegativity of Se relative to $\mathrm{S}$ is diminished in the cysteine thiolate fragments, there is still a decrease in 
$\psi^{*}{ }_{\mathrm{HOMO}} / \psi^{*} \beta$-LUMO energy gap (see fragment calculations shown in Figure 8 and Supporting Information) on going from $\mathrm{SCys}^{-}$to $\mathrm{SeCys}^{-}$, resulting in the decrease in $\mathrm{CT}$ energies.

However, the $\mathrm{d}-\mathrm{d}$ bands are more metal-centered and mixed with several ligand fragments and are, thus, less sensitive to the Se vs S difference relative to purely ligand-based orbitals, which are affected by the resulting change in the $\psi_{\mathrm{HOMO}}{ }^{*} / \psi^{*} \beta$-LUMO energy gap. However, the striking similarity in the MCD spectra of WT and $\mathrm{C} 112 \mathrm{SeC}$ azurin indicates that the two active sites have very similar geometric and electronic structures.

It is interesting to note that EXAFS analysis of WT and $\mathrm{C} 112 \mathrm{SeC}$ azurin indicates that the $\mathrm{Cu}-$ $\mathrm{Se}_{\mathrm{Cys}}$ bond distance in $\mathrm{C} 112 \mathrm{SeC}$ is $2.3 \AA$, $0.16 \AA$ longer than the $\mathrm{Cu}-\mathrm{S}_{\mathrm{Cys}}$ bond distance in WT, which is due to the larger covalent radius of Se compared to $S$ (difference in the covalent radius is $0.135 \AA$ ). ${ }^{22}$ Despite this difference in bond distance, the electronic structure of the two proteins is very similar. The larger radial distribution of the valence $4 p$ orbitals of $\mathrm{Se}$ compensate for the increase in bond distance, which results in a bonding interaction similar to that in WT azurin. The similarity of the MCD CT band intensities in WT and C112SeC azurin raises an interesting issue. Transitions observed in the $\mathrm{LT}$ absorption and MCD spectra were assigned as LF or CT transitions based on their relative intensity ratios. ${ }^{66,72,73}$ This is given by the $C_{0} / D_{0}$ ratio, where $C_{0}$ is the low-temperature MCD $C$-term intensity and $D_{0}$ is the dipole strength obtained from the absorption spectrum, which is calculated using the following equation, 66,74

$$
\frac{C_{0}}{D_{0}}=\frac{k T}{\mu_{\mathrm{B}} B}\left(\frac{\Delta \varepsilon}{\varepsilon}\right)_{\text {Max }}
$$

where $T$ is the temperature, $B$ is the applied external magnetic field strength, $k$ is the Boltzmann constant, $\mu_{\mathrm{B}}$ is the Bohr magneton, $\varepsilon$ is the absorption maximum in $\mathrm{M}^{-1} \mathrm{~cm}^{-1}$, and $\Delta \varepsilon$ is $\mathrm{MCD}$ intensity maximum measured in $\mathrm{M}^{-1} \mathrm{~cm}^{-1} \mathrm{~K}^{-1}$. In a low-symmetry system, such as in azurin $\left(\mathrm{C}_{1}\right.$ symmetry), the orbital degeneracy of all states is lifted; hence, all electronic transitions are polarized in one molecular direction. However, MCD intensity requires two perpendicular transition moments. In such cases, low-temperature $C$-term MCD intensity derives from spinorbit coupling (SOC), which can mix the two orthogonal transition dipole moments of different states. Hence, the $C_{0} / D_{0}$ will depend on the magnitude of SOC occurring at the centers involved in the transitions. Since the SOC parameter for $\mathrm{Cu}$ is greater than that for $\mathrm{N}$ or $\mathrm{S}\left(\xi_{3 \mathrm{~d}}(\mathrm{Cu}) \approx\right.$ $828 \mathrm{~cm}^{-1}>\approx \xi_{3 \mathrm{p}}(\mathrm{S}) 382 \mathrm{~cm}^{-1}>\xi_{2 \mathrm{p}}(\mathrm{N}) \approx 70 \mathrm{~cm}^{-1}$ ), the $\mathrm{Cu} \mathrm{d} \rightarrow \mathrm{d}$ transitions are expected to exhibit greater $C_{0} / D_{0}$ ratios than the ligand-based CT transitions in WT azurin. However, since in $\mathrm{C} 112 \mathrm{SeC}$ azurin the corresponding $\mathrm{S}_{\mathrm{Cys}} \rightarrow \mathrm{Cu} \mathrm{CT}$ transitions are replaced by $\mathrm{Se}_{\mathrm{Cys}} \rightarrow \mathrm{Cu}$ $\mathrm{CT}$ transitions, these bands might be expected to have larger $C_{0} / D_{0}$ ratios relative to WT since the SOC of Se is more than twice that of $\mathrm{Cu}\left(\xi_{4 \mathrm{p}}(\mathrm{Se}) \approx 1690 \mathrm{~cm}^{-1}\right)$. The experimentally determined $C_{0} / D_{0}$ ratios for both the $\mathrm{d} \rightarrow \mathrm{d}(\mathrm{LF})$ and $\mathrm{CT}$ transitions are, however, comparable in WT, M121SeM, and C112SeC azurin (Table 2). This insensitivity of the MCD intensity to the ligand SOC relates to the mechanism of low-temperature MCD intensity in the blue-copper site and is addressed in the Discussion section.

\subsection{Resonance Raman}

The resonance Raman (rR) spectra of blue-copper proteins obtained with excitation into the

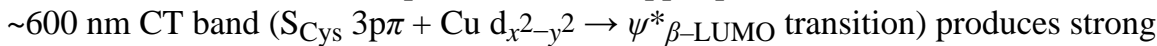
enhancement of three or more fundamental vibrational modes in the $330-460 \mathrm{~cm}^{-1}$ region. 13,75 It has been suggested that the multiplicity of these modes is due to coupling of the $\mathrm{Cu}-$ $\mathrm{S}$ stretch with internal modes of the cysteine ligand. ${ }^{76,77}$ The intensity-weighted average energy of these vibrations $\left(\left\langle v_{\mathrm{Cu}-\mathrm{S}}\right\rangle\right)$, where $\left\langle v_{\mathrm{Cu}-\mathrm{S}}\right\rangle=\Sigma_{i}\left(I_{i} v^{2}\right) / \Sigma_{i}\left(I_{i} v\right)$, has been used as an 
indicator of the $\mathrm{Cu}-\mathrm{S}_{\mathrm{Cys}}$ bond strength with a higher $\left\langle v_{\mathrm{Cu}-\mathrm{S}}\right\rangle$, indicating a stronger $\mathrm{Cu}-\mathrm{S}$ bond. 75

3.3.1. Comparison of WT and M121SeM Azurin-Figure 4 presents the rR spectra of WT and M121SeM azurin obtained with excitation at $647.1 \mathrm{~nm}$, into the intense S(Cys) 3p $\pi$ $\rightarrow$ Cu CT transition (band 4). The spectra for WT and M121SeM are very similar and show three bands centered around $410 \mathrm{~cm}^{-1}$. The intensity-weighted average energies of the $\mathrm{Cu}-$ $\mathrm{S}_{\text {Cys }}$ stretch were 407 and $402 \mathrm{~cm}^{-1}$ for WT and M121SeM, respectively. The variation of stretching force constant for an atom-pair can be correlated to the bond distance between them using Badger's rule. 78

$$
k=1.86\left(r_{\mathrm{e}}-d_{i j}\right)^{-1 / 3}
$$

where $k$ is the force constant, $r_{\mathrm{e}}$ is the equilibrium bond length, and the constant $d_{i j}$ is fixed for bonds between atoms of rows $i$ and $j$ of the Periodic Table. Using the bond distances obtained from EXAFS data and WT $\left\langle v_{\mathrm{Cu}-\mathrm{S}}\right\rangle$ as reference, the $\mathrm{Cu}-\mathrm{S}_{\mathrm{Cys}}$ bond distance estimated from Badger's rule for M121SeM is $2.16 \AA$, which is within error of the experimentally (EXAFS) obtained $\mathrm{Cu}-\mathrm{S}_{\mathrm{Cys}}$ distance of $2.18 \AA$. These results are indicative of a small decrease in the $\mathrm{Cu}-\mathrm{S}_{\mathrm{Cys}}$ force constant on going from WT to M121SeM azurin, consistent with a small decrease in the S K-pre-edge intensity.

3.3.2. Comparison of WT and C112SeC Azurin-A comparison of the rR spectra of WT and $\mathrm{C} 112 \mathrm{SeC}$ with excitation at $647.1 \mathrm{~nm}$ is also included in Figure 4. The spectrum of $\mathrm{C} 112 \mathrm{SeC}$ consists of one band at $333 \mathrm{~cm}^{-1}$ in contrast to the three-band spectrum of WT. Using the reduced masses of the $\mathrm{Cu}-\mathrm{Se}$ and $\mathrm{Cu}-\mathrm{S}$ pair in $\mathrm{C} 112 \mathrm{SeC}$ and $\mathrm{WT}$, respectively, and the $\mathrm{WT}\left\langle v_{\mathrm{Cu}-\mathrm{S}}\right\rangle\left(407 \mathrm{~cm}^{-1}\right)$ as a reference, a $\left\langle v_{\mathrm{Cu}-\mathrm{Se}}\right\rangle$ value of $317 \mathrm{~cm}^{-1}$ would reflect the mass change effect with no change in the $\mathrm{Cu}-\mathrm{X}$ force constant. The experimental value of 333 $\mathrm{cm}^{-1}$ indicates, at most, a small increase in the $\mathrm{Cu}-\mathrm{Se}$ force constant in $\mathrm{C} 112 \mathrm{SeC}$.

\subsection{Density Functional Theory}

3.4.1. Geometry Optimization-The results of the geometry optimization of the 141-atom models of WT, M121SeM, and C112SeC azurin are presented in Table 3. The structures of the M121SeM mutant and WT are very similar, and the $\mathrm{Cu}$-ligand distances are perturbed only slightly ( $\Delta d \leq 0.02 \AA$, Table 3). The structural changes are more significant in the $\mathrm{C} 112 \mathrm{SeC}$ mutant. The calculated $\mathrm{Cu}-\mathrm{Se}_{\mathrm{Cys}}$ distance is $2.31 \AA, 0.1 \AA$ longer relative to the calculated $\mathrm{Cu}-\mathrm{S}_{\mathrm{Cys}}$ distance in the WT (Table 3). Alternatively, the $\mathrm{Cu}-\mathrm{S}_{\mathrm{Met}}$ distance is $\sim 0.1 \AA$ shorter relative to that in $\mathrm{WT}$. The $\mathrm{Cu}-\mathrm{N}_{\mathrm{His}}$ and $\mathrm{Cu}-\mathrm{O}_{\mathrm{Gly}}$ distances undergo only very small changes upon $\mathrm{Se}_{\mathrm{Cys}}$ substitution.

3.4.2. Comparison of Wave-functions-The DFT calculations on WT, M121SeM, and $\mathrm{C} 112 \mathrm{SeC}$ azurin give a ground-state description that indicates a highly covalent $\mathrm{Cu}-\mathrm{S} / \mathrm{Se} \mathrm{Cys}_{\mathrm{s}}$ bond in all three structures, which is reflected in the composition of the $\beta$-spin $\psi^{*}$ LUMO (Table 4, Figure 5). In the WT model, the $\mathrm{Cu}$ and $\mathrm{S}_{\mathrm{Cys}}$ contributions to $\psi^{*}$ LUMO are $43.4 \%$ and $35.5 \%$, respectively (Table 4). As a result, the spin density is almost equally shared between these two atoms $\left(\mathrm{Cu}\right.$ and $\mathrm{S}_{\mathrm{Cys}} \mathrm{MPA}$ - and NPA-derived spin densities are $43 \%$ and $38-39 \%$, respectively). This description is in agreement with the experimental S K-edge XAS data (Table 1). The spin density of the $\mathrm{Cu}$ and $\mathrm{S}_{\mathrm{Cys}}$ atoms accounts for $\sim 79 \%$ of the total spin density of the system. The remaining $21 \%$ is mostly delocalized over the imidazole rings of the histidine ligands and the $\beta$-methylene $\mathrm{H}$-atoms of the $\mathrm{Cu}$-bound $\mathrm{Cys}$ residue. The contribution of $\mathrm{S}_{\mathrm{Met}}$ is very small $(0.1 \%)$, reflecting a very weak interaction between the half-occupied $\mathrm{Cu}$ 
$3 \mathrm{~d}_{x^{2}-y^{2}}$ orbital and the $\mathrm{S}_{\mathrm{Met}}$ donor orbital, consistent with the approximately perpendicular orientation of the $\mathrm{Cu}-\mathrm{S}_{\mathrm{Met}}$ with respect to the $\mathrm{Cu} \mathrm{d}_{x^{2}-y^{2}}$ plane.

Figure 5 shows a contour plot comparison of the WT with M121SeM azurin. The overall spindensity distribution (Table 4) is very similar to that in the WT; however, the contribution of the $\mathrm{Se}_{\mathrm{Met}}$ to $\psi^{*} \beta$-LUMO $(1.8 \%)$ is greater than the contribution of $\mathrm{S}_{\mathrm{Met}}$. There is no structural distortion in M121SeM, which indicates that the increased $\mathrm{S}_{\mathrm{Met}}$ donation to the ground state is because of the larger radial distribution of the Se $4 p$ relative to the $S 3 p$ orbital. The small increase in the $\mathrm{Cu}-\mathrm{Se}_{\mathrm{Met}}$ interaction leads to a slightly weaker $\mathrm{Cu}-\mathrm{S}_{\mathrm{Cys}}$ covalent interaction, as reflected in the changes in the $\psi^{*} \beta$-LUMO composition (decreased by $\sim 1 \%$ ) (Table 4 ).

In $\mathrm{C} 112 \mathrm{SeC}$, the ground-state wave-function is qualitatively very similar to that of the WT protein (Figure 5). The $\mathrm{Se}_{\mathrm{Cys}}$ and $\mathrm{Cu}$ contributions to $\psi^{*} \beta$-LUMO are $\sim 41 \%$ and $39 \%$ (Table 4). This indicates that $\mathrm{C} 112 \mathrm{SeC}$ has the strongest covalent interaction between unoccupied $\mathrm{Cu}$ $3 \mathrm{~d}_{x^{2}-y^{2}}$ orbital and $\mathrm{X}_{\mathrm{Cys}}$ relative to WT and M121SeM. The highly covalent $\mathrm{Cu}-\mathrm{Se} \mathrm{Cys}_{\mathrm{C}}$ bond description obtained from DFT calculations is consistent wih the small increase in the covalent component of the $\mathrm{Cu}-\mathrm{Se}_{\mathrm{Cys}}$ bond observed in the rR data. However, the increase incovalent interaction upon replacement of $\mathrm{S}_{\mathrm{Cys}}$ with $\mathrm{Se}_{\mathrm{Cys}}$ is very small (only $\sim 5 \%$ ), resulting in only a small perturbation to the ground-state wave-function.

3.4.3. TD-DFT-TD-DFT calculations were performed on WT azurin and the C112SeC mutant to compare to the experimental electronic absorption spectra. The results are presented in Figure 6 and are in good agreement with the experimental data (Figure 3). Both the calculated spectra contain an intense charge-transfer band $\left(\sim 16200 \mathrm{~cm}^{-1}\right.$ for the WT and $15200 \mathrm{~cm}^{-1}$ for the $\mathrm{C} 112 \mathrm{SeC}$ ), which corresponds to a $\beta$-spin electron transition from the $\mathrm{Cu} 3 \mathrm{~d}_{x^{2}-y^{2}+}$ $\mathrm{X}_{\mathrm{Cys}} p \pi$ occupied orbital to $\psi^{*} \beta$-LUMO. The calculated oscillator strength of this CT band in the $\mathrm{C} 112 \mathrm{SeC}$ mutant is slightly less than the corresponding oscillator strength in the WT. This small decrease in intensity is linked to a slightly smaller $\mathrm{Cu}-\mathrm{X}_{\mathrm{Cys}}$ overlap population (OP) in the $\mathrm{C} 112 \mathrm{SeC}$ mutant relative to $\mathrm{WT}$ azurin due to the longer $\mathrm{Cu}-\mathrm{X}_{\mathrm{Cys}}$ bond $(\mathrm{OP} \mathrm{Cu}-\mathrm{X}$ are -0.070 and -0.063 for the $\mathrm{WT}$ and $\mathrm{C} 112 \mathrm{SeC}$, respectively). The $\mathrm{d}-\mathrm{d}$ transitions in $\mathrm{C} 112 \mathrm{SeC}$ relative to WT are less shifted than the corresponding CT bands, since they are dominantly metal based and are mixed with several ligand fragments.

These results coupled with the experimental data indicate that replacement of $\mathrm{S}_{\mathrm{Cys}}$ with $\mathrm{Se}_{\text {Cys }}$ leads to a surprisingly small electronic structure perturbation. Although, as expected, the $\mathrm{Cu}-\mathrm{Se}$ bond does become stronger and more covalent relative to WT, the overall $\mathrm{S}$ character only increases by $\sim 5 \%$. This is even more intriguing given that a structural perturbation occurs on going from WT to $\mathrm{C} 112 \mathrm{SeC}\left(\mathrm{Cu}-\mathrm{X}_{\mathrm{Cys}}\right.$ is longer by $0.1 \AA$ and the $\mathrm{Cu}-\mathrm{X}_{\mathrm{Met}}$ is shorter by $\sim 0.1 \AA$ ). This is addressed in the next section.

\section{Discussion}

\subsection{Unique Spectroscopic Features of Blue-Copper Proteins}

$\mathrm{BC}$ proteins have been extensively studied by a wide range of spectroscopic methods, which have helped define the ligand field of the $\mathrm{Cu}$ center and quantify its covalent bonding interaction. However, there are several interesting issues related to these spectroscopies that have remained elusive. The mutation of $\mathrm{S}$ to $\mathrm{Se}$ in the equatorial cysteine and axial methionine has provided an excellent opportunity to probe these interactions and resolve a number of key spectroscopic issues.

4.1.1. $\mathrm{S}_{\text {Met }}$ Contribution to $\mathrm{S}$ K-edge XAS-S K-edge XAS provided the first quantitative measure of the $\mathrm{S}$ character in $\psi^{*} \beta$-LUMO of a BC protein $(\sim 38 \%) .{ }^{14}$ However, since bluecopper proteins contain a weak $\mathrm{Cu}-\mathrm{S}_{\mathrm{Met}}$ bond and LT abs and MCD spectra (consistent with 
other spectroscopic studies and DFT calculations) show a small contribution of the $\mathrm{S}_{\text {Met }}$ ligand to the ground-state wave-function, it has remained important to evaluate whether the $38 \% \mathrm{~S}$ character in the ground state observed from the $\mathrm{S}$ K-pre-edge intensity quantifies the $\mathrm{CuS}_{\mathrm{Cys}}$ interaction. In this study, although the pre-edge of M121SeM at $2469.0 \mathrm{eV}$ is very similar to that of the WT protein, the intensity is decreased by a small amount $(\sim 1-3 \%)$ (Figure 1). However, the $\mathrm{S}$ K-edge XAS spectra of $\mathrm{CuL} 1$, which has a $\mathrm{Cu}^{\mathrm{II}}-\mathrm{S}_{\text {thioether }}$ bonding interaction, was also measured, which indicates that the pre-edge of a $\mathrm{Cu}-\mathrm{S}_{\mathrm{Met}}$ complex occurs at 2472.1 $\mathrm{eV}, \sim 3.1 \mathrm{eV}$ above the $\mathrm{Cu}-\mathrm{S}_{\text {thiolate }}$ pre-edge transition observed in BC proteins. This clearly shows that the $\mathrm{Cu}-\mathrm{S}_{\mathrm{Met}}$ bond does not contribute to the pre-edge intensity at $\sim 2469 \mathrm{eV}$ in BC proteins and the $38 \% \mathrm{~S}$ character in the ground-state wave-function only involves $\mathrm{S}_{\mathrm{Cys}}$.

4.1.2. Kinematic Coupling in Resonance Raman Spectroscopy-X-ray crystal structures of $\mathrm{BC}$ proteins show that the dihedral angle formed by the $\mathrm{S}_{\mathrm{CyS}}$ is highly conserved as are the $\mathrm{Cu}-\mathrm{S}_{\gamma}-\mathrm{C}_{\beta}-\mathrm{C}_{\alpha}$ and the $\mathrm{S}_{\gamma}-\mathrm{C}_{\beta}-\mathrm{C}_{\alpha}-\mathrm{N}$ dihedral angles $\left(\sim 170^{\circ}\right) .{ }^{13}$ This leads to near coplanarity of the $\mathrm{Cu}-\mathrm{S}_{\mathrm{Cys}}$ bond with the cysteine side-chain and part of the polypeptide backbone. It has been suggested that this results in coupling between the $\mathrm{Cu}-\mathrm{S}_{\mathrm{Cys}}$ vibration and the cysteine deformation modes. ${ }^{13,77,79}$ Because of the mass effect, for the C112SeC mutant, the $\mathrm{Cu}-\mathrm{X}_{\mathrm{Cys}}$ stretching frequency decreased from 410 to $333 \mathrm{~cm}^{-1}$. Interestingly, the three-peak vibrational pattern observed in the rR spectrum of WT is replaced by a single peak in the rR spectrum of C112SeC (Figure 4), even though DFT calculations suggest minimal structural change upon $\mathrm{Se}_{\mathrm{Cys}}$ mutation (the calculated active=site geometries of the 141-atom WT and C112SeC azurin are very similar (see Figure 5)). To evaluate the factors resulting in the loss of kinematic coupling in $\mathrm{C} 112 \mathrm{SeC}$ azurin, frequency calculations were performed on the small-molecule analogues; $\left[(\mathrm{tpz}) \mathrm{Cu}\left(\mathrm{XC}_{6} \mathrm{~F}_{5}\right)\right](\mathrm{X}=\mathrm{Se}$ and $\mathrm{S})$. Figure 7 shows the calculated magnitude of $\mathrm{Cu}-\mathrm{X}$ motion contributing to the vibrational normal modes between 280 and 420 $\mathrm{cm}^{-1}$. The frequencies of these modes for $\left[(\mathrm{tpz}) \mathrm{Cu}\left(\mathrm{SC}_{6} \mathrm{~F}_{5}\right)\right]$ are in reasonable agreement with the observed spread of frequencies in the published $\mathrm{rR}$ data. ${ }^{80}$ In contrast to the calculated mixing of $\mathrm{Cu}-\mathrm{S}$ distortion over four normal modes in $\left[(\mathrm{tpz}) \mathrm{Cu}\left(\mathrm{SC}_{6} \mathrm{~F}_{5}\right)\right](311,342,365$, and $\left.409 \mathrm{~cm}^{-1}\right)$, the calculated $\mathrm{Cu}-\mathrm{Se}$ distortion is mostly restricted to a single low-frequency normal mode $\left(\sim 290 \mathrm{~cm}^{-1}\right)$ in $\left[(\mathrm{tpz}) \mathrm{Cu}\left(\mathrm{SeC}_{6} \mathrm{~F}_{5}\right)\right]$ (Figure 5). Finally, frequency calculations were also performed on the hypothetical $\left[(\mathrm{tpz}) \mathrm{Cu}\left({ }^{32} \mathrm{SeC}_{6} \mathrm{~F}_{5}\right)\right]$ complex in which the mass of $\mathrm{Se}$ is modified to be equal to $\mathrm{S}$. Interestingly, the calculations reveal that, similar to the $\mathrm{Cu}-\mathrm{S}$ motion in [(tpz)-Cu( $\left.\left.\mathrm{SC}_{6} \mathrm{~F}_{5}\right)\right]$, the $\mathrm{Cu}-{ }^{32} \mathrm{Se}$ distortion is mixed into four normal modes (305, 337,360 , and $393 \mathrm{~cm}^{-1}$ ). This indicates that the low $\mathrm{Cu}-\mathrm{Se}$ stretching frequency eliminates mechanical coupling of the $\mathrm{Cu}-\mathrm{Se}$ distortion with other ligand normal modes, and when the mass of Se is lowered, the mixing is reestablished. Thus, the absence of multiple bands in the rR spectrum of $\mathrm{C} 112 \mathrm{SeC}$ indicates that the lower frequency of the $\mathrm{Cu}-\mathrm{Se}_{\mathrm{Cys}}$ stretch uncouples it from the cysteine deformation modes and results in a single vibrational feature. These results support the kinematic coupling between the $\mathrm{Cu}-\mathrm{S}_{\mathrm{Cys}}$ and the cysteine deformation modes in BC proteins.

4.1.3. Effect of Ligand Spin-Orbit Coupling on MCD $\boldsymbol{C}$-Terms-At low temperature, the $C$-term dominates the MCD spectrum of paramagnetic systems. Two mechanisms contribute to nonzero $C$-term intensity: (i) SOC between two nearby excited states $|J\rangle$ and $\mid$ $K>$ to which orthogonal transitions are made from the ground state $\mid A>$ and (ii) SOC between the ground state $|A\rangle$ and a low-lying excited state $\mid K>$ from which two orthogonal transitions can be made to a single excited state $|J\rangle$. The first mechanism leads to oppositely signed $C$ terms with equal intensities (pseudo- $A$ term), while the second leads to deviation from the MCD sum-rule. Both these mechanisms involve two perpendicularly polarized CT transitions, which have SOC along a third, mutually orthogonal direction. Defining the molecular coordinate system in azurin such that the $\mathrm{S} / \mathrm{Se}_{\mathrm{Met}}$ is along the $z$-direction, the Cys- and His-based ligand- 
to-metal CT transitions are $x, y$-polarized and require the SOC along the $z$-axis $\left(L_{z}\right)$. The $C_{0}$ term associated with two such CT transitions is given by $74,81,82$

$$
\begin{aligned}
& C_{0}(A \rightarrow J)= \\
& -\frac{1}{6} \sum_{K \neq A, J} g_{z} \Delta_{K J}{ }^{-1}\left(D_{x}^{K A} D_{y}^{A J}-D_{y}^{K A} D_{\mathrm{x}}^{A J}\right) L_{z}^{K J}
\end{aligned}
$$

where $g_{z}$ is the effective $g$-value in the $z$-direction, $\Delta^{-1}{ }_{K J}$ is the energy difference between the two excited states, $|J\rangle$ and $|K\rangle, D_{x}^{J A}$ is the component of the transition dipole moment between $|A\rangle$ and $|J\rangle$ in the $x$-direction, and $L_{z}^{K J}$ is the spin-orbit coupling operator. Since $L_{z}^{K J}$ is effectively a localized, single-center, one-electron operator, the center involved in SOC around the $z$-direction must be simultaneously present in both orthogonal CT transitions. This can only involve the central $\mathrm{Cu}$ atom, which overlaps both donor orbitals. Hence, nonzero ligand-tometal charge transfer $C$-term intensity involves a metal-based SOC mechanism. This explains the similar $C_{0} / D_{0}$ ratios in WT, M121SeM, and C112SeC azurin (Figure 3). Although the donor orbitals are dominantly ligand-based with very different $\mathrm{SOC}$ parameters on $\mathrm{S}$ versus Se, this difference does not affect the $C$-term intensity. The effect of this metal-centered SOC mechanism can be seen in the previously observed MCD spectra of Pf AOR, a W(V) containing enzyme with dithiolato ligands in comparison to the data on Rs DMSOR, a structurally similar enzyme with a $\mathrm{Mo}(\mathrm{V})$ center. 83,84 The $C$-term intensity is an order of magnitude higher for Pf AOR since the SOC of $\mathrm{W}_{5 \mathrm{~d}}$ is $\sim 4$ times higher than that of $\mathrm{Mo}_{3 \mathrm{~d}}$.

\section{2. $\mathrm{Cu}-\mathrm{S}$ Versus $\mathrm{Cu}-\mathrm{Se}$ Bonding}

Resonance Raman data and DFT calculations reveal that the ground-state wave-functions $\left(\psi^{*} \beta\right.$-LUMO) of $\mathrm{WT}$ and $\mathrm{C} 112 \mathrm{SeC}$ are very similar, with only a small increase in the $\mathrm{Cu}-$ $\mathrm{X}_{\mathrm{Cys}}$ covalency in $\mathrm{C} 112 \mathrm{SeC}$. A similar trend in metal-S/Se covalency has been previously observed in $\left[\mathrm{Fe}_{2} \mathrm{Se}_{2}(\mathrm{SPh})_{2}\right]^{2-}$ and $\left[\mathrm{Fe}_{2} \mathrm{~S}_{2}(\mathrm{SPh})_{2}\right]^{2-}$ where the $\mathrm{Fe}-\mathrm{S}$ and $\mathrm{Fe}-\mathrm{Se}$ covalencies were found to be similar. ${ }^{85}$ This is surprising, since the larger and "softer" Se might have been expected to have a much stronger $\mathrm{Se}-\mathrm{Cu}\left(4 \mathrm{p} \pi-\mathrm{Cu} 3 \mathrm{~d}_{\left.x^{2}-y^{2}\right)}\right.$ interaction relative to $\mathrm{S}-\mathrm{Cu}(3 \mathrm{p} \pi-$ $\mathrm{Cu} 3 \mathrm{~d}_{x^{2}-y^{2}}$ ). To analyze the factors affecting $\mathrm{M}-\mathrm{S}$ vs M-Se bonding, DFT calculations were performed on $\left[\mathrm{Cu}^{\mathrm{II}}(\mathrm{tpz})\left(\mathrm{XC}_{6} \mathrm{~F}_{5}\right)\right]$ model complexes (tpz $=$ trispyrazolyl borate, $\left.\mathrm{X}=\mathrm{S}, \mathrm{Se}\right)$ to correlate interaction energies and bond lengths and to quantify the nature of chemical bonding. 86,87 The TD-DFT calculated absorption spectra (Figure 6) of $\left[\mathrm{Cu}^{\mathrm{II}}(\mathrm{tpz})\left(\mathrm{SC}_{6} \mathrm{~F}_{5}\right)\right]$ and [CuII (tpz) $\left.\left(\mathrm{SeC}_{6} \mathrm{~F}_{5}\right)\right]$ are very similar to those of WT azurin and the $\mathrm{C} 112 \mathrm{SeC}$ mutant, respectively, and show the same shifts in energy and intensity as in the proteins. This indicates that a reasonable theoretical comparison of the two models can be made to interpret the protein experimental data.

Relevant calculated parameters for $\left[\mathrm{Cu}^{\mathrm{II}}(\mathrm{tpz})\left(\mathrm{SC}_{6} \mathrm{~F}_{5}\right)\right]$ and $\left[\mathrm{Cu}^{\mathrm{II}}(\mathrm{tpz})\left(\mathrm{SeC}_{6} \mathrm{~F}_{5}\right)\right]$ are summarized in Table 5. The electronic interaction energy between the $\mathrm{Cu}^{\mathrm{II}}$-tpz fragment and the $\mathrm{SeC}_{6} \mathrm{~F}_{5}{ }^{-}$ligand in $\left[\mathrm{Cu}^{\mathrm{II}}(\mathrm{tpz})\left(\mathrm{SeC}_{6} \mathrm{~F}_{5}\right)\right]$ is calculated to be $0.8 \mathrm{kcal} \mathrm{mol}^{-1}$ smaller than the electronic interaction energy between the $\left[\mathrm{Cu}^{\mathrm{II}}(\mathrm{tpz})\right]^{+}$fragment and the $\mathrm{SC}_{6} \mathrm{~F}_{5}{ }^{-}$ligand in $\left[\mathrm{Cu}^{\mathrm{II}}(\mathrm{tpz})\left(\mathrm{SC}_{6} \mathrm{~F}_{5}\right)\right]$. Such a small difference in the interaction energies in the two systems originates from the fact that $\mathrm{Cu}-\mathrm{X}$ covalency in the two is very close $(27 \% \mathrm{~S}$ character in $\left[\mathrm{Cu}^{\mathrm{II}}-(\mathrm{tpz})\left(\mathrm{SC}_{6} \mathrm{~F}_{5}\right)\right]$ and $32 \%$ Se character in $\left[\mathrm{CuII}(\mathrm{tpz})\left(\mathrm{SeC}_{6} \mathrm{~F}_{5}\right)\right]$ and the $\mathrm{Cu}-\mathrm{S}$ and $\mathrm{Cu}-\mathrm{Se}$ bond orders are 1.07 and 1.08, respectively; see Table 5). In these two complexes, the covalent bonding between the $\mathrm{XC}_{6} \mathrm{~F}_{5}{ }^{-}$ligand and $\mathrm{Cu}^{\mathrm{II}}$ is limited to $\sigma$ and $\pi$ ligand-to-metal donation. There are only two donor orbitals involved: the near-degenerate, highest occupied $\mathrm{p} \sigma$, and $\mathrm{p} \pi$ orbitals of the $\mathrm{XC}_{6} \mathrm{~F}_{5}{ }^{-}$ligand (see the orbital interaction diagram, Figure 8, right). In the $\left[\mathrm{Cu}^{\mathrm{II}}(\mathrm{tpz})\left(\mathrm{SC}_{6} \mathrm{~F}_{5}\right)\right]$ model, the $\alpha$-spin $\mathrm{Cu}^{\mathrm{II}}\left(\mathrm{tpz}^{+}-\mathrm{SC}_{6} \mathrm{~F}_{5}{ }^{-}\right.$orbital interactions involve only the $\mathrm{p} \sigma$ orbital of the thiolate, which donates 0.16 electrons to the metal fragment. The $\beta$-spin orbital 
interactions involve both $\mathrm{p} \sigma$ and $\mathrm{p} \pi$ and 0.16 and 0.41 electrons are transferred to the metal fragment from these two orbitals, respectively. In the $\left[\mathrm{Cu}^{\mathrm{II}}(\mathrm{tpz})-\left(\mathrm{SeC}_{6} \mathrm{~F}_{5}\right)\right]$ model, the situation is very similar: $\mathrm{p} \sigma$ donates 0.17 electrons ( $\alpha$-spin) and 0.17 electrons $(\beta$-spin) to the metal fragment and $\mathrm{p} \pi$ donates 0.44 electrons $(\beta$-spin).

There are two factors that influence the extent of $\mathrm{Cu}-\mathrm{X}$ covalent bonding. The first is the fragment orbital overlap (which determines the magnitude of the corresponding Fock matrix element $\left.\left\langle\psi_{i}|F| \psi_{j}\right\rangle\right)$, and the second is the relative energies between the interacting orbitals $\left(\psi_{i}\right.$ and $\psi_{j}$ ) of the two fragments,

$$
E_{i \rightarrow j}=-\theta \frac{\left\langle\psi_{i}|F| \psi_{i}\right\rangle^{2}}{E_{j}-E_{i}}
$$

where $\theta$ is the electron occupation of the resulting bonding orbital ( 2 for a doubly occupied MO and 1 for a singly occupied MO). DFT calculations show that, for $\psi^{*} \beta$-LUMO, the Cu $\mathrm{d}_{x^{2}-y^{2}}$ fragment orbital involved in the $\pi$ ligand-to-metal donation has the same orbital overlaps, 0.06 (Table 5) with the p $\pi$ orbitals of $\mathrm{SC}_{6} \mathrm{~F}_{5}{ }^{-}$and $\mathrm{SeC}_{6} \mathrm{~F}_{5}{ }^{-}$in the corresponding complexes (in which the $\mathrm{Cu}-\mathrm{S}$ and $\mathrm{Cu}-\mathrm{Se}$ distances are 2.20 and $2.32 \AA$, respectively) (Table 5). In addition, the fragment calculations show that the donor orbitals (HOMO and HOMO-1) of the free ligands have very similar energies (Table 5). Since both the orbital overlap and the relative fragment energies are very similar, the corresponding bonding interactions between the donor orbitals of the ligand and the acceptor orbitals of the metal result in very similar orbital stabilization energies and covalencies for the two complexes.

The result that the donor orbitals of $\mathrm{SC}_{6} \mathrm{~F}_{5}{ }^{-}$and $\mathrm{SeC}_{6} \mathrm{~F}_{5}{ }^{-}$are so close in energy (which indicates that the electronegativities of the Se and $\mathrm{S}$ atoms in $\mathrm{SC}_{6} \mathrm{~F}_{5}{ }^{-}$and $\mathrm{SeC}_{6} \mathrm{~F}_{5}{ }^{-}$are very close) is not obvious considering that free $\mathrm{S}$ and Se have significantly different atomic electronegativities $\chi$ (Mulliken values of $\chi$ are $6.22 \mathrm{eV}$ for $\mathrm{S}$ and $5.89 \mathrm{eV}$ for Se). ${ }^{88,89} \mathrm{On}$ the basis of the electronegativity of free atoms, the energies of S-based donor orbitals are expected to be significantly lower (by at least $0.3 \mathrm{eV}$ ) compared to the Se-based donor orbitals. Insight into this deviation from the atomic electronegativities comes from the fact that, although local atomic electronegativity is a function of atomic charge, the hardness $\eta_{(\mathrm{S}}=4.14 \mathrm{eV}$ and $\eta_{\mathrm{Se}}$ $=3.86 \mathrm{eV}$ ) indicates how sensitive the electronegativity is with respect to change in atomic charge. In the ligand $\mathrm{XC}_{6} \mathrm{~F}_{5}{ }^{-}$, the charge is distributed over the entire ligand framework to equalize the chemical potential. DFT calculations indicate that the $\mathrm{S}$ atom in $\mathrm{SC}_{6} \mathrm{~F}_{5}{ }^{-}$has the same charge as the Se atom in $\mathrm{SeC}_{6} \mathrm{~F}_{5}{ }^{-}\left(q_{\mathrm{NPA}}=-0.45\right.$ a.u. $)$. This similarity in $\mathrm{S}$ and Se charges in the ligand molecular framework results in very similar local electronegativities of $\mathrm{S}$ and $\mathrm{Se}$ ( $2.08 \mathrm{eV}$ for $\mathrm{S}$ and $2.03 \mathrm{eV}$ for $\mathrm{Se}$ ). Thus, the corresponding $\mathrm{S}$ - and Se-donor orbitals ( $\sigma$ and $\mathrm{p} \pi$ of the $\mathrm{XC}_{6} \mathrm{~F}_{5}{ }^{-}$ligand) have very similar energies, allowing for similar bonding interactions as observed experimentally in the WT and $\mathrm{C} 112 \mathrm{SeC}$ mutant of azurin.

This study shows that the M-thiolate/selenolate bond strengths are very similar in $\mathrm{Cu}-\mathrm{S}_{\mathrm{Cys}}$ and $\mathrm{Cu}-\mathrm{Se}_{\mathrm{Cys}}$ systems and provides important insight into other $\mathrm{M}-\mathrm{X}_{\mathrm{Cys}}(\mathrm{X}=\mathrm{S}, \mathrm{Se})$ containing proteins involved in redox processes. These include the heterometallic NiFeSe hydrogenases 90,91 (which contain a Ni-Se ${ }_{\text {Cys }}$ bond) and the $\mathrm{Mo} / \mathrm{W}$ containing formate dehydrogenases (FDHs) (which contain a Mo/W-Se ${ }_{\mathrm{Cys}}$ bond). ${ }^{92-94}$ This study reveals that the frontier molecular orbitals (FMOs) of $\mathrm{RSe}^{-}$and $\mathrm{RS}^{-}$are very similar, which explains the similarity in the active-site electronic structures and the catalytic rates of $\mathrm{NiFeSe}$ and $\mathrm{NiFe}$ $\left(\mathrm{S}_{\mathrm{Cys}}\right.$ instead of $\left.\mathrm{Se}_{\mathrm{Cys}}\right)$, both of which occur naturally. ${ }^{95} \mathrm{In}$ FDHs, however, replacing the WT Mo-Se ${ }_{\mathrm{Cys}}$ bond by Mo-S $\mathrm{S}_{\mathrm{Cys}}$ leads to only $0.3 \%$ catalytic rate. ${ }^{96}$ Interestingly, although the bond strength and electronic structure of the active site Mo-S/Se are very similar, the intrinsic 
$\mathrm{pKa}$ of the $\mathrm{Se}_{\mathrm{Cys}}$ and $\mathrm{S}_{\mathrm{Cys}}$ are significantly different (5.2 and 8.3, respectively). 97,98 These results indicate that the presence of $\mathrm{Se}_{\mathrm{Cys}}$ in lieu of $\mathrm{S}_{\mathrm{Cys}}$ does not tune the redox reactivity of the metal center, but instead, the $\mathrm{pKa}$ of the selenolate could be required for efficient catalysis.

In summary, a spectroscopic and DFT investigation of WT, M121SeM, and C112SeC azurin has been performed, which has elucidated interesting spectroscopic issues. S K-edge XAS on WT, M121SeM, and the $\mathrm{Cu}^{\mathrm{II}}-\mathrm{S}_{\text {thioether }}$ model $\mathrm{CuL} 1$ show that the $38 \% \mathrm{~S}$ character in the $\psi^{*} \beta$-LUMO only reflects the SCys ligand. Resonance Raman data on WT and C112SeC azurin support the model that mechanical coupling of the $\mathrm{Cu}-\mathrm{S}$ stretch with the cysteine deformation modes in WT result in the multiple-peak rR spectrum in the $400 \mathrm{~cm}^{-1}$ region. The much lower stretching frequency of the $\mathrm{Cu}-\mathrm{Se}$ mode $\left(333 \mathrm{~cm}^{-1}\right)$ decouples it from the protein vibrational models, resulting in a single peak. UV-vis and MCD data on WT, M121SeM, and C112SeC give similar $C_{0} / D_{0}$ ratios, which show that it is the SOC on the metal center that determines MCD intensity. The spectroscopic data show that the $\mathrm{Cu}-\mathrm{S}_{\mathrm{Cys}}$ and $\mathrm{Cu}-\mathrm{Se} \mathrm{Cys}_{\mathrm{C}}$ bonds have very similar covalencies at the bond distances of 2.1 and $2.3 \AA$, respectively, which is supported by DFT calculations. These calculations indicate that fragment orbital overlaps and energies are very similar for the $\mathrm{S}$ and $\mathrm{Se}$ in their thiolate/selenolate fragment environment, which leads to very similar ground-state covalencies and overall bonding.

\section{Acknowledgments}

This work was supported by NSF CHE-0446304 (E.I.S.), NIH RR-01209 (K.O.H.), NSF CHE98-76457 and NSF CHE-0552008 (Y.L), and NIH GM50730 (T.D.P.S). SSRL operations are funded by the Department of Energy, Office of Basic Energy Sciences. The SSRL Structural Molecular Biology program is supported by the National Institutes of Health, National Center for Research Resources, Biomedical Technology Program and by the Department of Energy, Office of Biological and Environmental Research.

\section{References}

1. Sykes AG. Adv Inorg Chem 1991;36:377-408.

2. Gray HB, Malmström BG, Williams RJP. J Biol Inorg Chem 2000;5:551-559. [PubMed: 11085645]

3. Messerschmidt A. Struct Bonding 1998;90:37-68.

4. Solomon EI, Szilagyi RK, DeBeer George S, Basumallick L. Chem Rev 2004;104:419-458. [PubMed: 14871131]

5. Solomon EI, Penfield KW, Gewirth AA, Lowery MD, Shadle SE, Guckert JA, LaCroix LB. Inorg Chim Acta 1996;243:67-78.

6. Malmström BG, Wittung-Stafshede P. Coord Chem Rev 1999;185-6:127-140.

7. Paraskevopoulos K, Sundararajan M, Surendran R, Hough MA, Eady RR, Hillier IH, Hasnain SS. Dalton Trans 2006;3067-:3076.

8. Nar H, Messerschmidt A, Huber R, van der Kamp M, Canters GW. J Mol Biol 1991;221:765-772. [PubMed: 1942029]

9. Romero A, Hoitink CWG, Nar H, Huber R, Messerschmidt A, Canters GW. J Mol Biol 1993;229:10071021. [PubMed: 8383207]

10. Dennison C. Coord Chem Rev 2005;249:3025-3054.

11. Lowery MD, Solomon EI. Inorg Chim Acta 1992;200:233-243.

12. Penfield KW, Gewirth AA, Solomon EI. J Am Chem Soc 1985;107:4519-29.

13. Han J, Adman ET, Beppu T, Codd R, Freeman HC, Huq L, Loehr TM, Sanders-Loehr J. Biochemistry 1991;30:10904-10913. [PubMed: 1932014]

14. Shadle SE, Pennerhahn JE, Schugar HJ, Hedman B, Hodgson KO, Solomon EI. J Am Chem Soc 1993;115:767-776.

15. Crane BR, Di Bilio AJ, Winkler JR, Gray HB. J Am Chem Soc 2001;123:11623-11631. [PubMed: 11716717]

16. Lowery MD, Guckert JA, Gebhard MS, Solomon EI. J Am Chem Soc 1993;115:3012-3013. 
17. Adman, ET. Advances in Protein Chemistry. Vol. 42. Academic Press; San Diego, CA: 1991.

18. Severinov K, Muir TW. J Biol Chem 1998;273:16205-16209. [PubMed: 9632677]

19. Muir TW, Sondhi D, Cole PA. Proc Natl Acad Sci USA 1998;95:6705-6710. [PubMed: 9618476]

20. Berry SM, Ralle M, Low DW, Blackburn NJ, Lu Y. J Am Chem Soc 2003;125:8760-8768. [PubMed: 12862470]

21. Berry SM, Gieselman MD, Nilges MJ, van der Donk WA, Lu Y. J Am Chem Soc 2002;124:20842085. [PubMed: 11878940]

22. Ralle M, Berry SM, Nilges MJ, Gieselman MD, van der Donk WA, Lu Y, Blackburn NJ. J Am Chem Soc 2004;126:7244-7256. [PubMed: 15186162]

23. Hay MT, Ang MC, Gamelin DR, Solomon EI, Antholine WE, Ralle M, Blackburn NJ, Massey PD, Wang XT, Kwon AH, Lu Y. Inorg Chem 1998;37:191-198.

24. Hay M, Richards JH, Lu Y. Proc Natl Acad Sci USA 1996;93:461-464. [PubMed: 8552661]

25. Hedman B, Frank P, Gheller SF, Roe AL, Newton WE, Hodgson KO. J Am Chem Soc 1988;110:3798-3805.

26. DeBeer George S, Metz M, Szilagyi RK, Wang HX, Cramer SP, Lu Y, Tolman WB, Hedman B, Hodgson KO, Solomon EI. J Am Chem Soc 2001;123:5757-5767. [PubMed: 11403610]

27. George, GN. EXAFSPAK \& EDG_FIT. Stanford Synchrotron Radiation Laboratory, Stanford Linear Accelerator Center, Stanford University; Stanford, CA: 2000.

28. Allendorf MD, Spira DJ, Solomon EI. Proc Natl Acad Sci USA 1985;82:3063-3067. [PubMed: 2987909]

29. Browett WR, Fucaloro AF, Morgan TV, Stephens PJ. J Am Chem Soc 1983;105:1868-1872.

30. Pople, JA., et al. Gaussian 03, revision C02. 2004.

31. Becke AD. J Chem Phys 1993;98:5648-5652.

32. Schäfer A, Huber C, Ahlrichs R. J Chem Phys 1994;100:5829-5835.

33. Rassolov VA, Pople JA, Ratner MA, Windus TL. J Chem Phys 1998;109:1223-1229.

34. Hariharan PC, Pople JA. Theor Chim Acta 1973;28:213-222.

35. Francl MM, Hehre WJ, Binkley JS, Gordon MS, DeFrees DJ, Pople JA. J Chem Phys 1982;77:36453665.

36. Gorelsky SI, Lever ABP. J Organomet Chem 2001;635:187-196.

37. Gorelsky, SI. AOMix. Department of Chemistry, York University; Toronto, ON: 1997. http://www.sg-chem.net

38. Mulliken RS. J Chem Phys 1955;23:1841-1846.

39. Mulliken RS. J Chem Phys 1955;23:1833-1840.

40. Mulliken RS. J Chem Phys 1955;23:2343-2346.

41. Mulliken RS. J Chem Phys 1955;23:2338-2342.

42. Reed AE, Weinstock RB, Weinhold F. J Chem Phys 1985;83:735-746.

43. Mayer I. Int J Quantum Chem 1986;29:73-84.

44. Mayer I. Int J Quantum Chem 1986;29:477-483.

45. Mayer I. Theor Chim Acta 1985;67:315-322.

46. Mayer I. Chem Phys Lett 1983;97:270-274.

47. Neese, F. ORCA-An ab initio, DFT and Semiempirical Electronic Structure Package, version 2.5. University of Bonn; Germany: 2007.

48. Perdew JP, Burke K, Wang Y. Phys Rev B 1998;57:14999.

49. Perdew JP. Phys Rev B 1986;33:8822-8824.

50. Becke AD. Phys Rev A 1988;38:3098-3100. [PubMed: 9900728]

51. McGrath MP, Radom L. J Chem Phys 1991;94:511-516.

52. Krishnan R, Binkley JS, Seeger R, Pople JA. J Chem Phys 1980;72:650-654.

53. Curtiss LA, McGrath MP, Blaudeau JP, Davis NE, Binning RC, Radom L. J Chem Phys 1995; 103:6104-6113.

54. Note that the active site in azurin has a strong $\mathrm{Cu}-\mathrm{S}_{\mathrm{cys}}$ interaction ( $40 \% \mathrm{~S}$ character in ground state) while the $\mathrm{Cu}-\mathrm{S}_{\text {thioether }}$ is relatively weak in $\mathrm{CuL1}$ (13\% over the two $\mathrm{S}$ atoms in ground state). This 
indicates that the ligand field in azurin is closer to that in $\mathrm{CuL} 1$ than suggested by their respective coordination numbers.

55. Basumallick L, DeBeer George S, Randall DW, Hedman B, Hodgson KO, Fujisawa K, Solomon EI. Inorg Chim Acta 2002;337:357-365.

56. Randall DW, DeBeer George S, Holland PL, Hedman B, Hodgson KO, Tolman WB, Solomon EI. J Am Chem Soc 2000;122:11632-11648.

57. Randall DW, DeBeer George S, Hedman B, Hodgson KO, Fujisawa K, Solomon EI. J Am Chem Soc 2000;122:11620-11631.

58. A pre-edge feature might be expected in the Se K-edge spectrum of C112SeC. However, the spectra reported in J. Am. Chem. Soc. 2004, 126, 7244-7256 do not exhibit a pre-edge transition. This likely reflects overlap of the pre-edge feature with the Se $1 \mathrm{~s} \rightarrow 4 \mathrm{p}+$ continuum rising edge and the low resolution at the $\mathrm{Se} \mathrm{K}$-edge $(\sim 3 \mathrm{eV})$.

59. The dipole integral $I(s)$ has been experimentally determined for a free thiolate ligand. The $\% \mathrm{~S}$ character in the ground state of WT and M121SeM have been calculated using an $I(s)$ value of 8.47.

60. Pratt RC, Mirica LM, Stack TDP. Inorg Chem 2004;43:8030-8039. [PubMed: 15578842]

61. George SJ, Lowery MD, Solomon EI, Cramer SP. J Am Chem Soc 1993;115:2968-2969.

62. Pickering TJ, Prince RC, Divers T, George GN. FEBS Lett 1998;441:11-14. [PubMed: 9877155]

63. Pickering IJ, George GN, Van Fleet-Stalder V, Chasteen TG, Prince RC. J Biol Inorg Chem 1999;4:791-794. [PubMed: 10631611]

64. The small feature observed in the second derivative spectrum of WT at $\sim 2472.5 \mathrm{eV}$ corresponds to the $\mathrm{Cys}(\mathrm{S})-(\mathrm{S})$ Cys disulfide bond present in azurin.

65. The pre-edge peak expected for the $\mathrm{Cu}-\mathrm{S}_{\mathrm{Met}}$ interaction in $\mathrm{C} 112 \mathrm{SeC}$ is not observed since it overlaps with the rising edge features from the seven additional $\mathrm{S}$ atoms and one disulfide bond.

66. Gewirth AA, Solomon EI. J Am Chem Soc 1988;110:3811-3819.

67. Solomon EI, Randall DW, Glaser T. Coord Chem Rev 2000;200:595-632.

68. Solomon EI, Gorelsky SI, Dey A. J Comput Chem 2006;27:1415-1428. [PubMed: 16807974]

69. The $\mathrm{Cu}-\mathrm{S}_{\mathrm{Met}}$ is defined to be along the $z$-axis. The two $\mathrm{Cu}-\mathrm{N}_{\mathrm{His}}$ and $\mathrm{CuS} \mathrm{S}_{\mathrm{Cys}}$ are in the $x y$ plane.

70. Werst MM, Davoust CE, Hoffman BM. J Am Chem Soc 1991;113:1533-1538.

71. Ryde U, Olsson MHM, Pierloot K, Roos BO. J Mol Biol 1996;261:586-596. [PubMed: 8794878]

72. Basumallick L, Szilagyi RK, Zhao YW, Shapleigh JP, Scholes CP, Solomon EI. J Am Chem Soc 2003;125:14784-14792. [PubMed: 14640653]

73. Basumallick L, Sarangi R, DeBeer George S, Elmore B, Hooper AB, Hedman B, Hodgson KO, Solomon EI. J Am Chem Soc 2005;127:3531-3544. [PubMed: 15755175]

74. Gerstman BS, Brill AS. J Chem Phys 1985;82:1212-30.

75. Blair DF, Campbell GW, Schoonover JR, Chan SI, Gray HB, Malmström BG, Pecht I, Swanson BI, Woodruff WH, Cho WK, English AM, Fry HA, Lum V, Norton KA. J Am Chem Soc 1985; 107:575566.

76. Dong SL, Spiro TG. J Am Chem Soc 1998;120:10434-10440.

77. Qiu D, Dasgupta S, Kozlowski PM, Goddard WA, Spiro TG. J Am Chem Soc 1998;120:1279112797.

78. Badger RM. J Chem Phys 1934;2:128.

79. Andrew CR, Han J, den Blaauwen T, van Pouderoyen G, Vijgenboom E, Canters GW, Loehr TM, Sanders-Loehr J. J Biol Inorg Chem 1997;2:98-107.

80. Gorelsky SI, Basumallick L, Vura-Weis J, Sarangi R, Hodgson KO, Hedman B, Fujisawa K, Solomon EI. Inorg Chem 2005;44:4947-4960. [PubMed: 15998022]

81. Yoon J, Mirica LM, Stack TDP, Solomon EI. J Am Chem Soc 2005;127:13680-13693. [PubMed: 16190734]

82. Neese F, Solomon EI. Inorg Chem 1999;38:1847-1865. [PubMed: 11670957]

83. Johnson MK, Rees DC, Adams MWW. Chem Rev 1996;96:2817-2839. [PubMed: 11848842]

84. Koehler BP, Mukund S, Conover RC, Dhawan IK, Roy R, Adams MWW, Johnson MK. J Am Chem Soc 1996;118:12391-12405. 
85. Rose K, Shadle SE, Glaser T, de Vries S, Cherepanov A, Canters GW, Hedman B, Hodgson KO, Solomon EI. J Am Chem Soc 1999;121:2353-2363.

86. DFT calculations were performed at the B3LYP/TZVP and B3LYP/6-311+G* level of theory.

87. The $\left[\mathrm{Cu}^{\mathrm{II}}(\mathrm{tpz})\left(\mathrm{XC}_{6} \mathrm{~F}_{5}\right)\right]$ model has been recently shown to be good model for the blue-copper protein active site.

88. Mulliken RS. J Chem Phys 1935;3:573-585.

89. Mulliken RS. J Chem Phys 1935;3:586-591.

90. Garcin E, Vernede X, Hatchikian EC, Volbeda A, Frey M, Fontecilla-Camps JC. Structure 1999;7:557-566. [PubMed: 10378275]

91. Fontecilla-Camps JC, Volbeda A, Cavazza C, Nicolet Y. Chem Rev 2007;107:4273-4303. [PubMed: 17850165]

92. Raaijmakers H, Teixeira S, Dias JM, Almendra MJ, Brondino CD, Moura I, Moura JJG, Romao MJ. J Biol Inorg Chem 2001;6:398-404. [PubMed: 11372198]

93. Boyington JC, Gladyshev VN, Khangulov S, Stadtman TC, Sun PD. Science 1997;275:1305-1308. [PubMed: 9036855]

94. Hille R. Chem Rev 1996;96:2757-2816. [PubMed: 11848841]

95. Stein M, Lubitz W. Phys Chem Chem Phys 2001;3:5115-5120.

96. Axley MJ, Bock A, Stadtman TC. Proc Natl Acad Sci USA 1991;88:8450-8454. [PubMed: 1924303]

97. Raaijmakers HCA, Romão MJ. J Biol Inorg Chem 2006;11:849-854. [PubMed: 16830149]

98. Stadtman TC. Annu Rev Biochem 1990;59:117-127. 


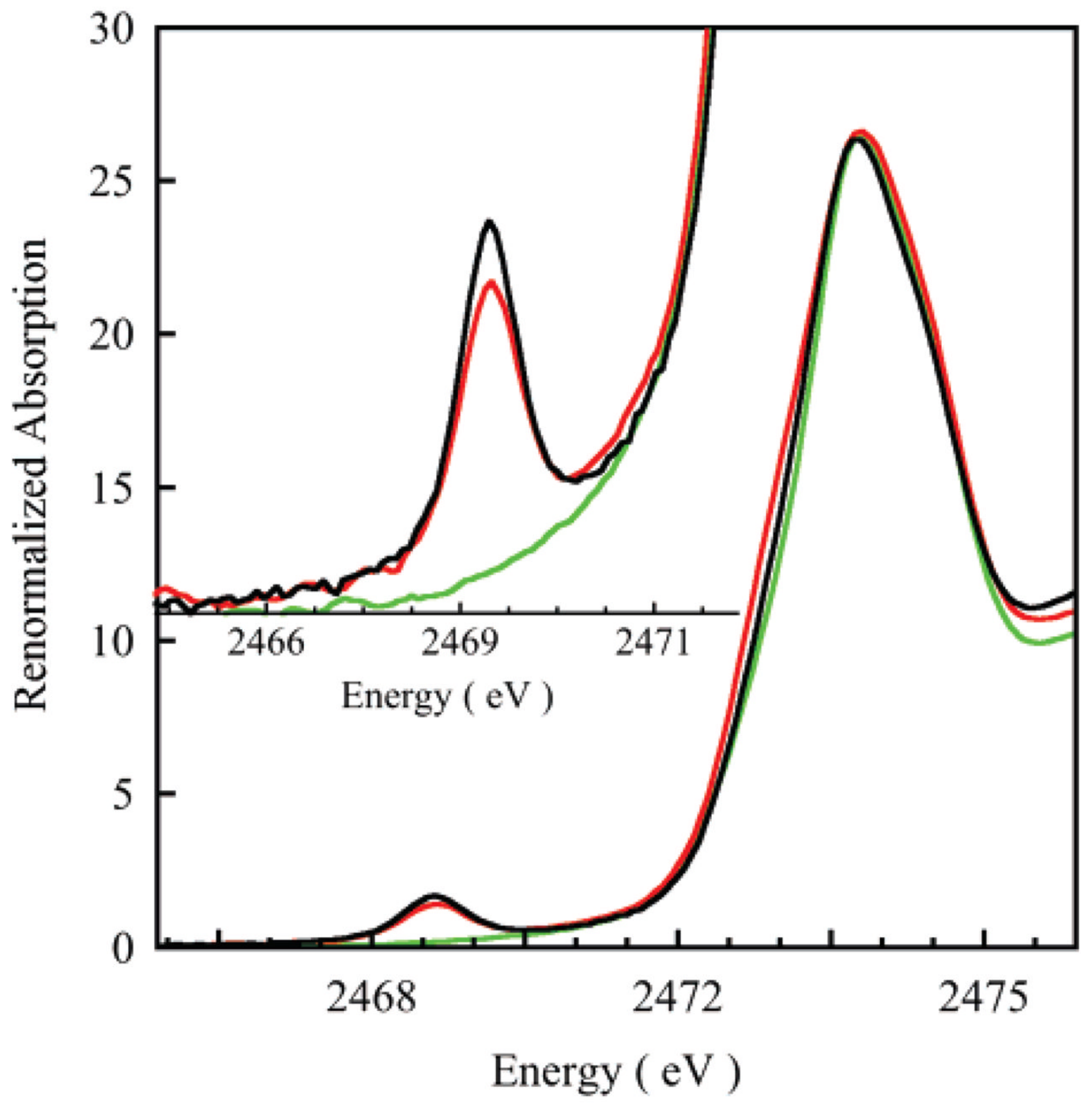

Figure 1.

S K-edge X-ray absorption spectra of WT azurin (black line), M121SeM (red line), and $\mathrm{C} 112 \mathrm{SeC}$ (green line) azurins. Inset shows the expanded pre-edge region. The spectra have been renormalized in each case to account for noncoordinating S-containing amino acids in the proteins. 


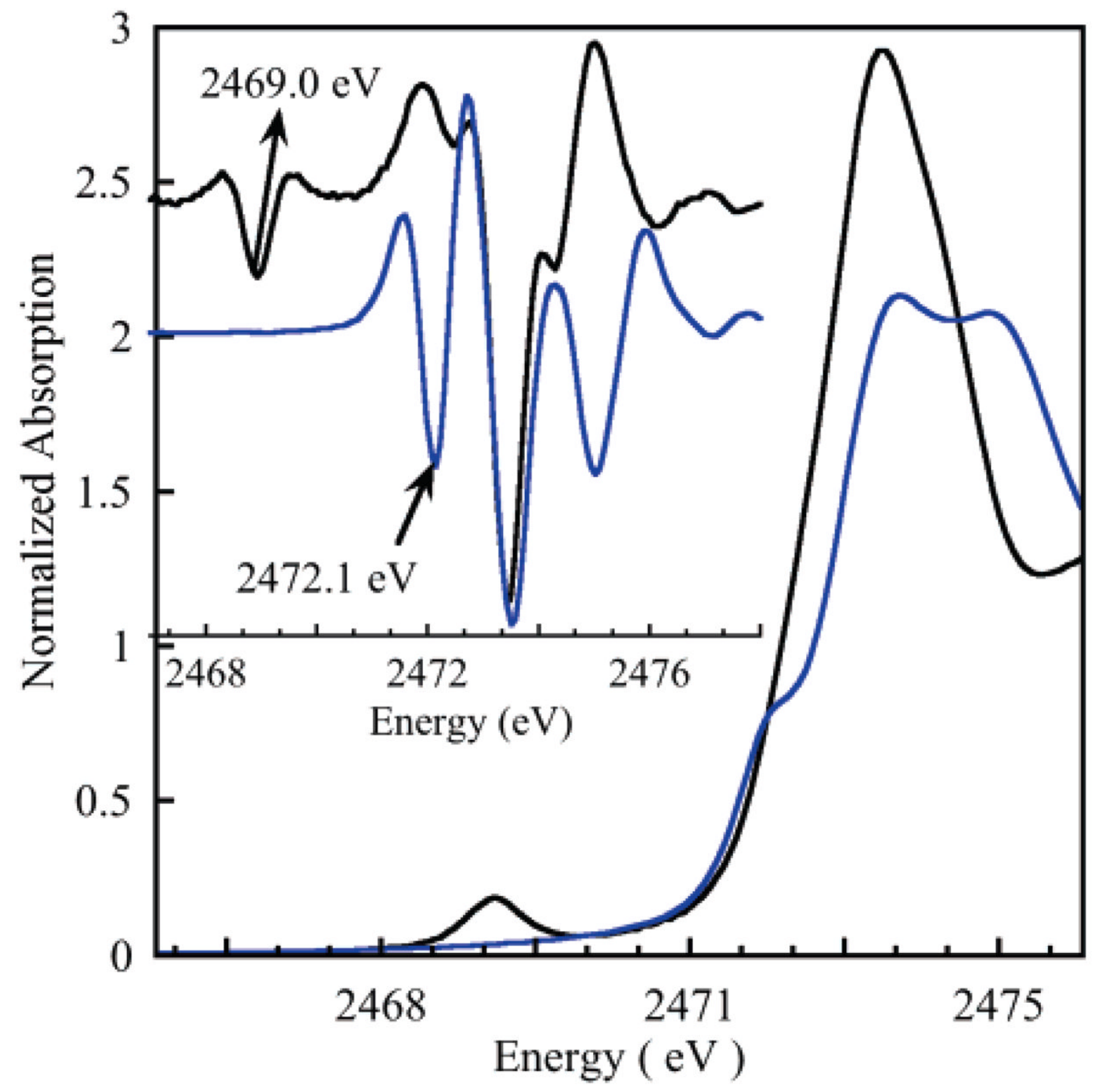

Figure 2.

$\mathrm{S}$ K-edge X-ray absorption spectra of WT azurin (black line) and the $\mathrm{Cu}-\mathrm{S}_{\text {thioether }}$ complex (CuL1) (blue line). Inset shows the second-derivative spectra. The pre-edge energy positions have been marked in both cases. 

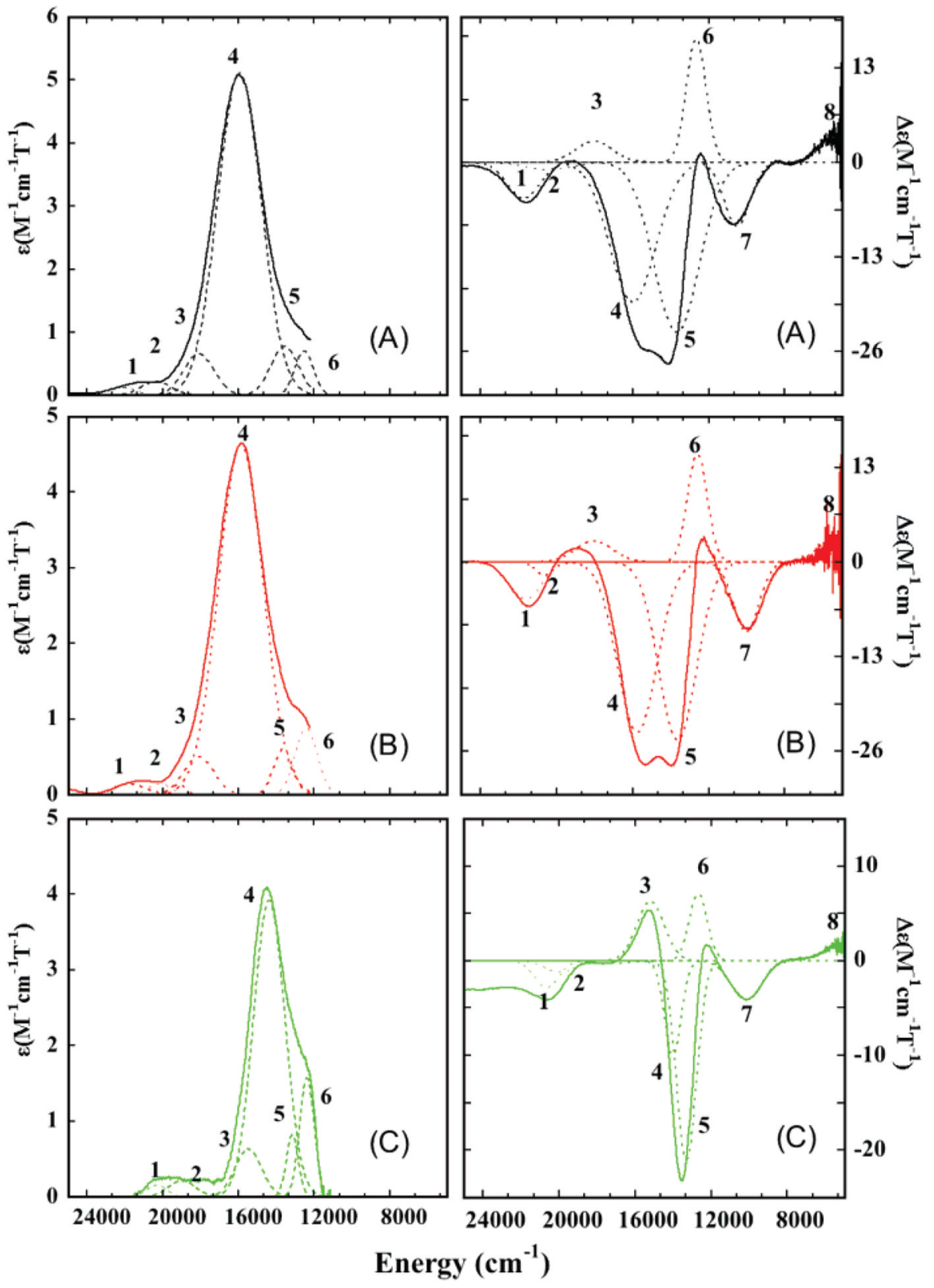

Figure 3.

Electronic absorption (left panel) and magnetic circular dichroism (right panel) spectra of (A) WT (black line), (B) M121SeM (red line), and (C) C112SeC (green line) azurins. Simultaneous Gaussian fits require eight bands to fit the data, which have been depicted with dashed lines. The bands have been labeled 1-8 for all three proteins. 


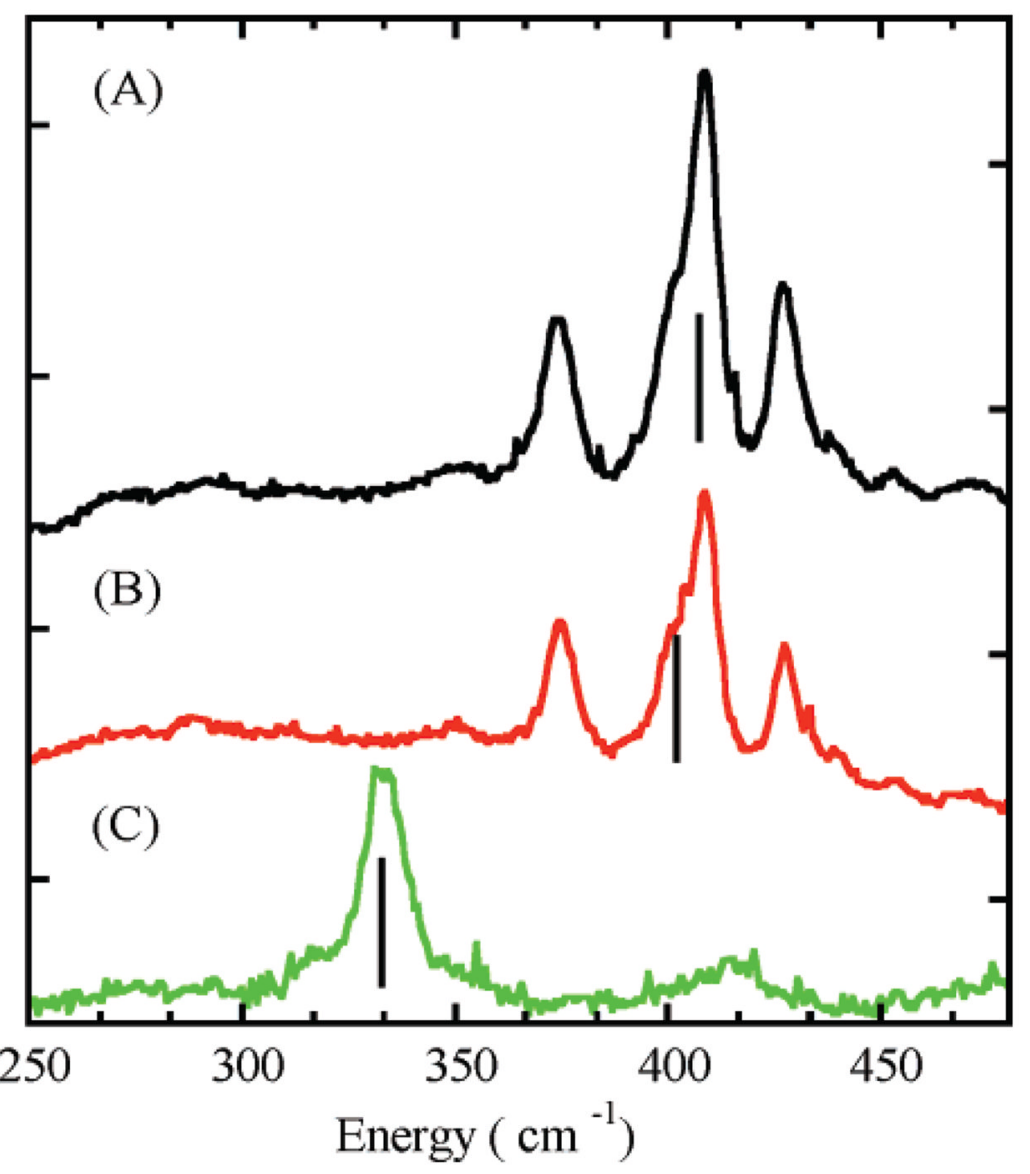

Figure 4.

Resonance Raman spectra obtained upon excitation at $647.1 \mathrm{~nm}$ for WT(black line), M121SeM (red line), and $\mathrm{C} 112 \mathrm{SeC}$ (green line) azurins. Lines mark the position of the intensity-weighted average of the $\mathrm{Cu}-\mathrm{S}$ vibrations. 


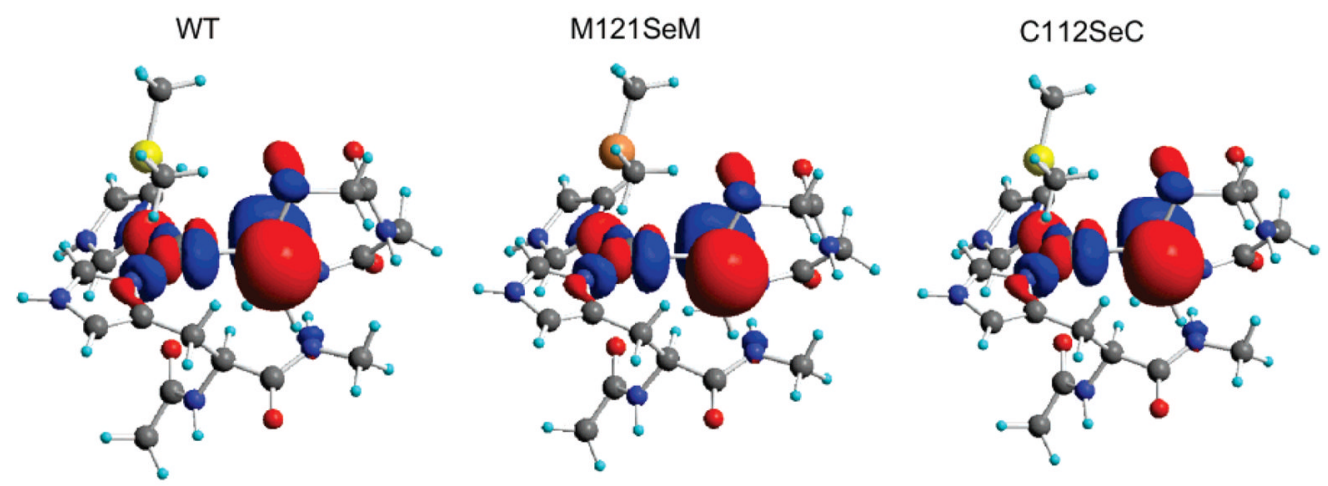

Figure 5.

$\psi^{*} \beta$-LUMO of the 141 -atom azurin model (the isocontour value is 0.03 a.u.). The contour plots indicate very similar ground-state wave-functions of the three proteins with only small quantitative differences. 


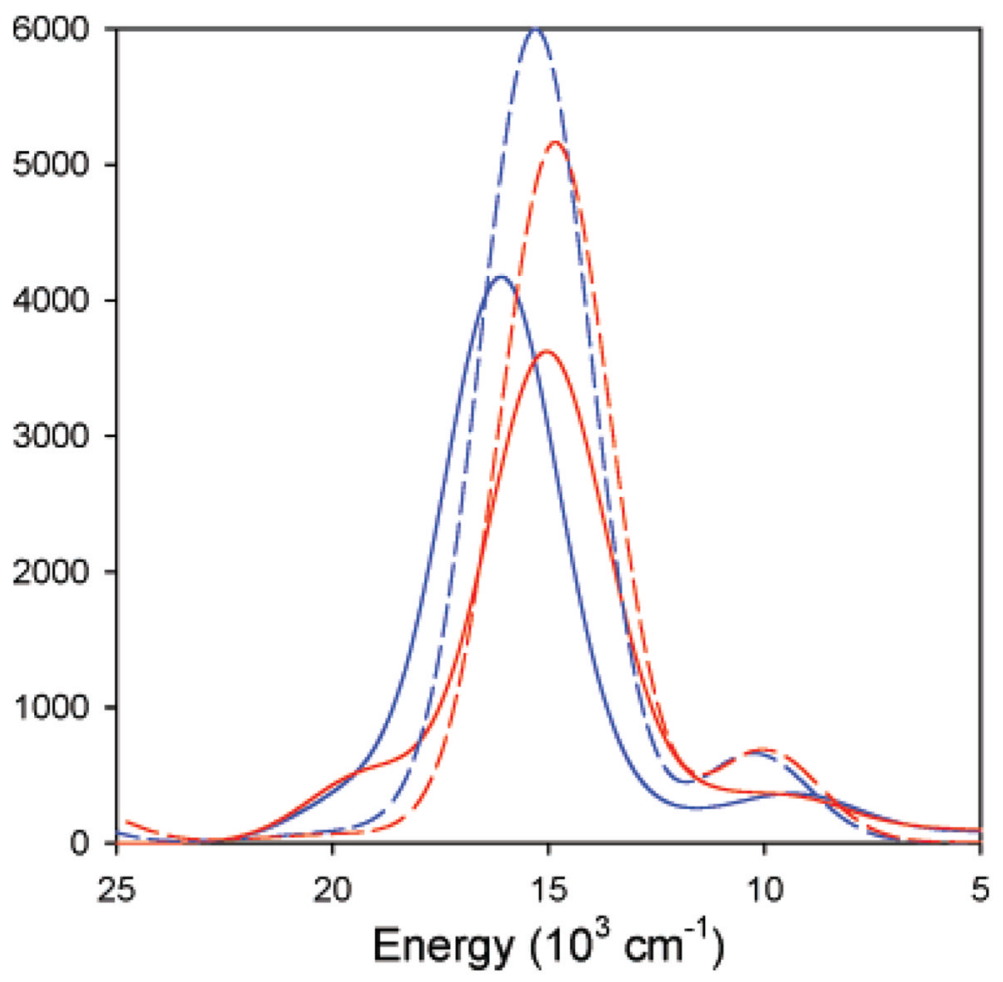

Figure 6.

TD-DFT-calculated spectra of WT azurin (black dotted line), the C112SeC mutant (red dotted line), $\left[\mathrm{Cu}^{\mathrm{II}}(\mathrm{tpz})\left(\mathrm{SC}_{6} \mathrm{~F}_{5}\right)\right]$ (black solid line), and $\left[\mathrm{Cu}^{\mathrm{II}}(\mathrm{tpz})\left(\mathrm{SeC}_{6} \mathrm{~F}_{5}\right)\right]$ (red solid line). 


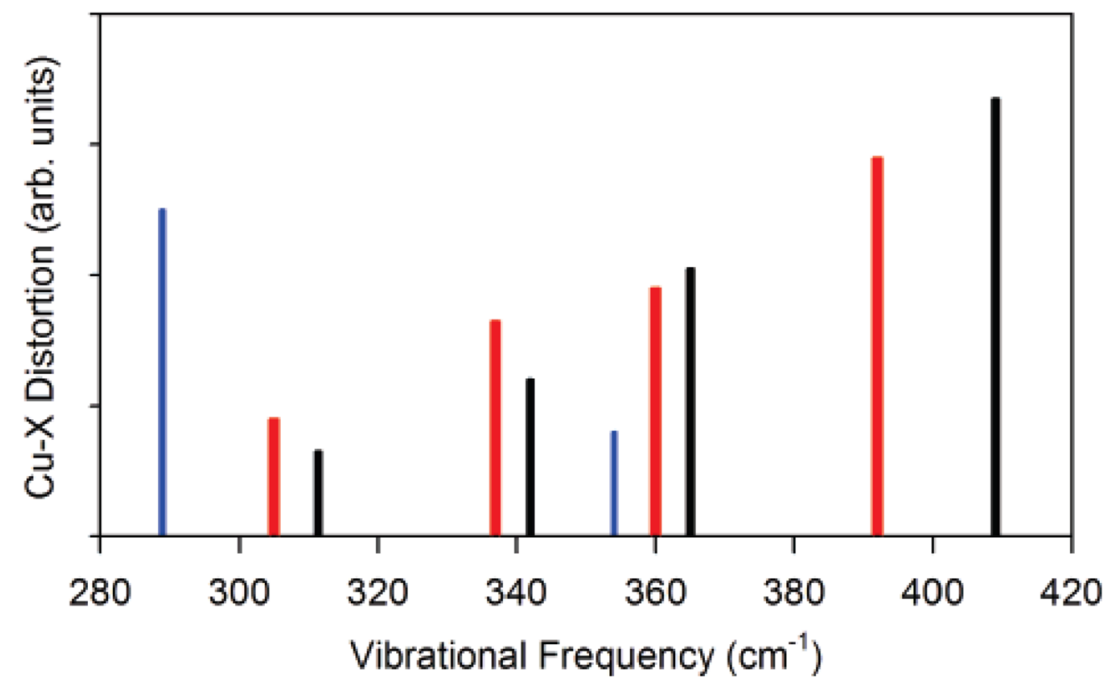

Figure 7.

DFT calculated $\mathrm{Cu}-\mathrm{X}$ distortion (arbitrary units) along normal modes for $\left[(\mathrm{tpz}) \mathrm{Cu}\left(\mathrm{XC}_{6} \mathrm{~F}_{5}\right)\right]$; $\mathrm{X}=\mathrm{S}$ (black line), $\mathrm{X}=\mathrm{Se}$ (blue line), and $\mathrm{X}={ }^{32} \mathrm{Se}$ (red line). 


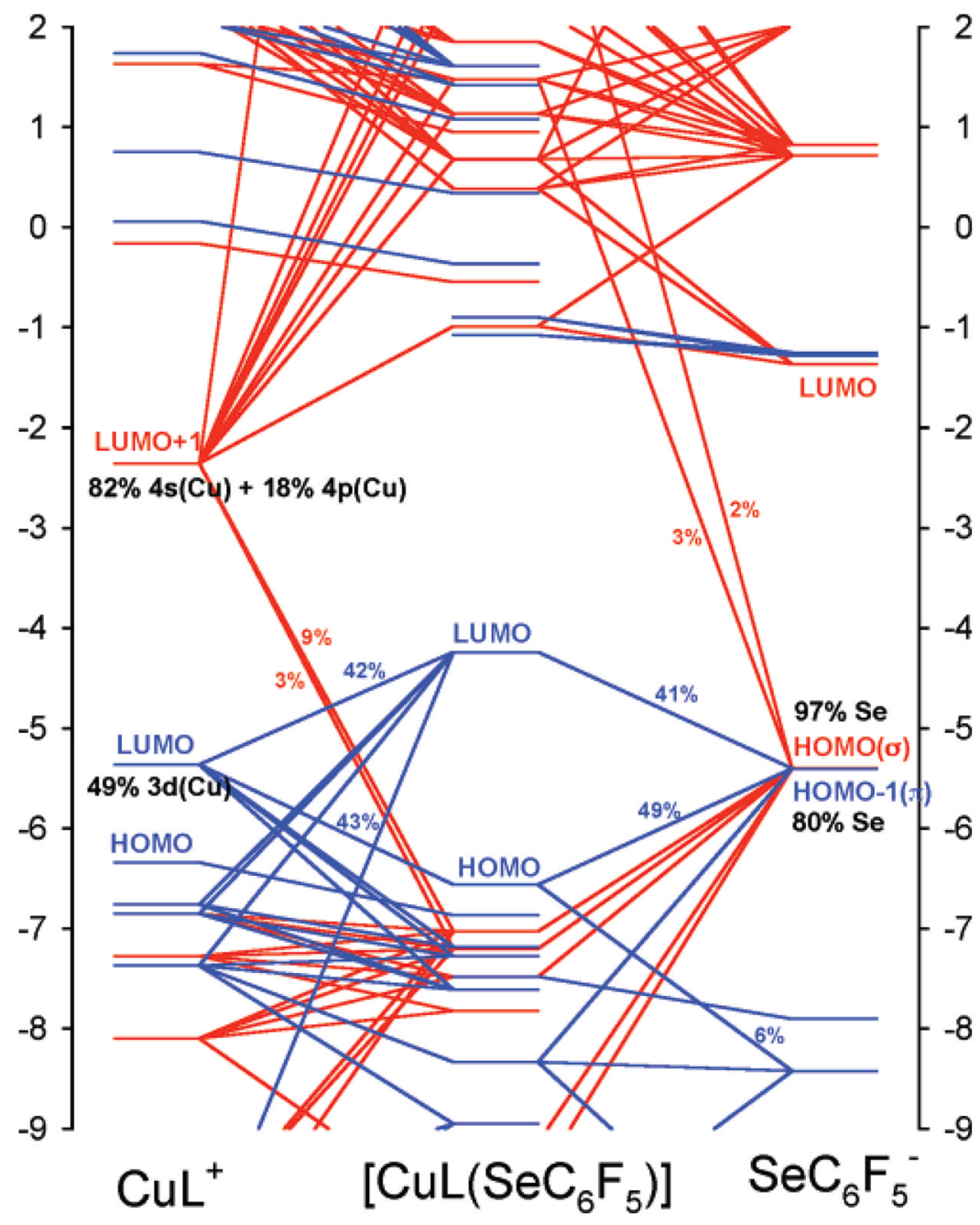

Figure 8.

Interaction diagram for $\beta$-spin molecular orbitals of $\left[\mathrm{Cu}^{\mathrm{II}}(\mathrm{tpz})-\left(\mathrm{SeC}_{6} \mathrm{~F}_{5}\right)\right]$ with $[\mathrm{CuII}(\mathrm{tpz})]^{+}$and $\mathrm{SeC}_{6} \mathrm{~F}_{5}{ }^{-}$as fragments and the corresponding $\sigma$ and $\pi$ interactions are shown in red and blue. The molecular orbitals of the $\mathrm{Cu}(\mathrm{tpz})^{+}$and $\mathrm{SeC}_{6} \mathrm{~F}_{5}{ }^{-}$fragments are shifted by 4.0 and $-4.5 \mathrm{eV}$, respectively. The interaction diagram for $\beta$-spin molecular orbitals of $\left[\mathrm{Cu}^{\mathrm{II}}-(\mathrm{tpz})\left(\mathrm{SC}_{6} \mathrm{~F}_{5}\right)\right]$ is presented in Figure S4.80 The interaction diagram for $\alpha$-spin molecular orbitals is very similar. However, since the $\alpha$-spin $\mathrm{Cu} d_{x^{2}-y^{2}}$ fragment orbital is occupied, there is no net contribution to bonding from the $\pi$ ligand-to-metal donation from this spin-orbital. 


\section{Sulfur K-Edge XAS Results}

Table 1

\begin{tabular}{|c|c|c|c|}
\hline azurin & pre-edge energy $^{a}(\mathrm{eV})$ & $\underset{(\mathrm{eV})}{\mathrm{1s} \rightarrow \mathrm{pp \text {transitionenergy }} b}$ & $\begin{array}{l}\% \text { S character in } \\
\psi_{\beta-\text { LUMO }}^{*}\end{array}$ \\
\hline WT & 2469.0 & 2473.4 & $40 \%$ \\
\hline M121SeM & 2469.0 & 2473.4 & $37.5 \%$ \\
\hline $\mathrm{C} 112 \mathrm{SeC}$ & & 2473.5 & \\
\hline
\end{tabular}

${ }^{a}$ The error in the energy position is estimated to be $\pm 0.1 \mathrm{eV}$.

$b$ Determined from the second derivative spectra.

${ }^{c}$ Error in $\% \mathrm{~S}$ character due to data processing and fitting is $\pm 3 \%$. 


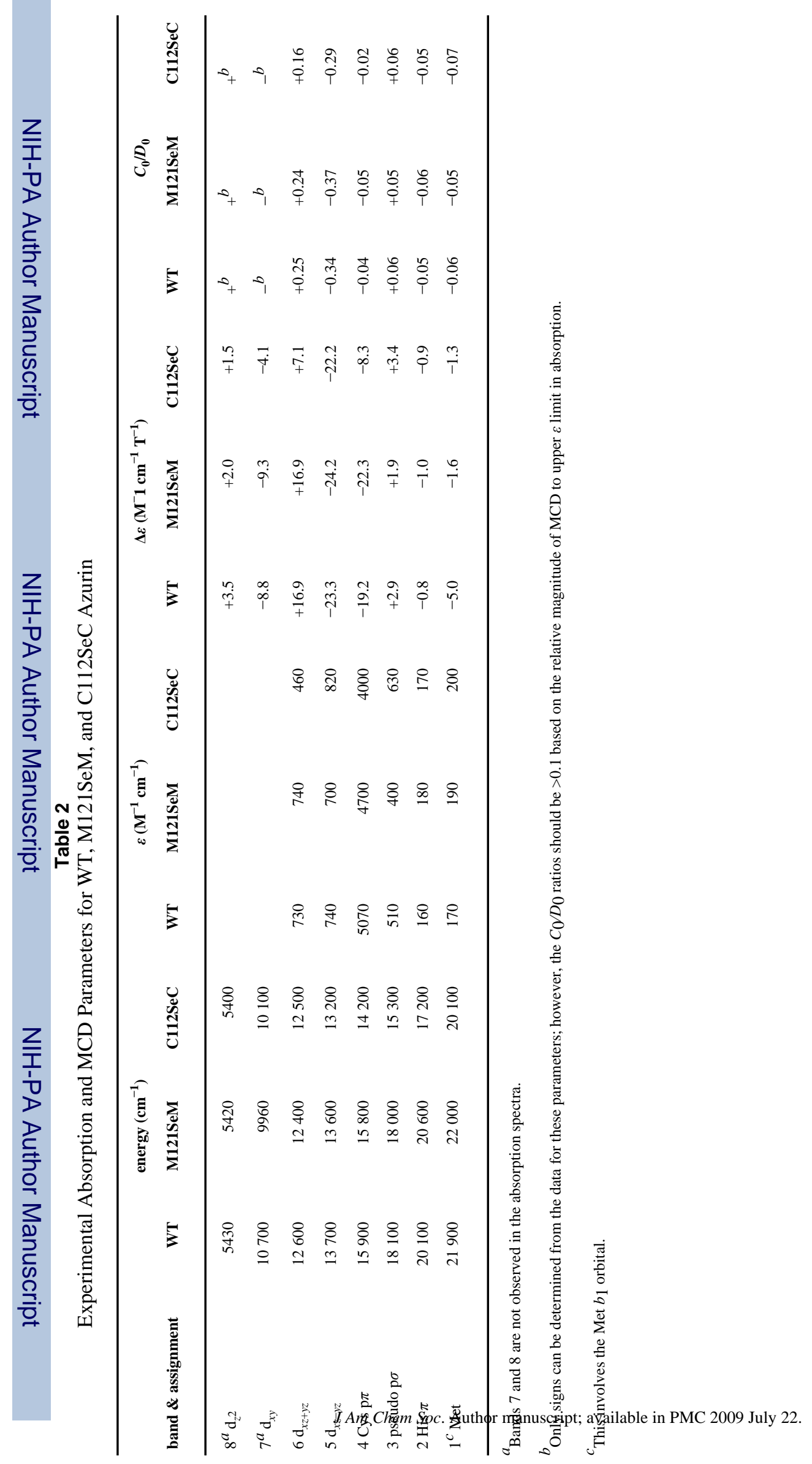




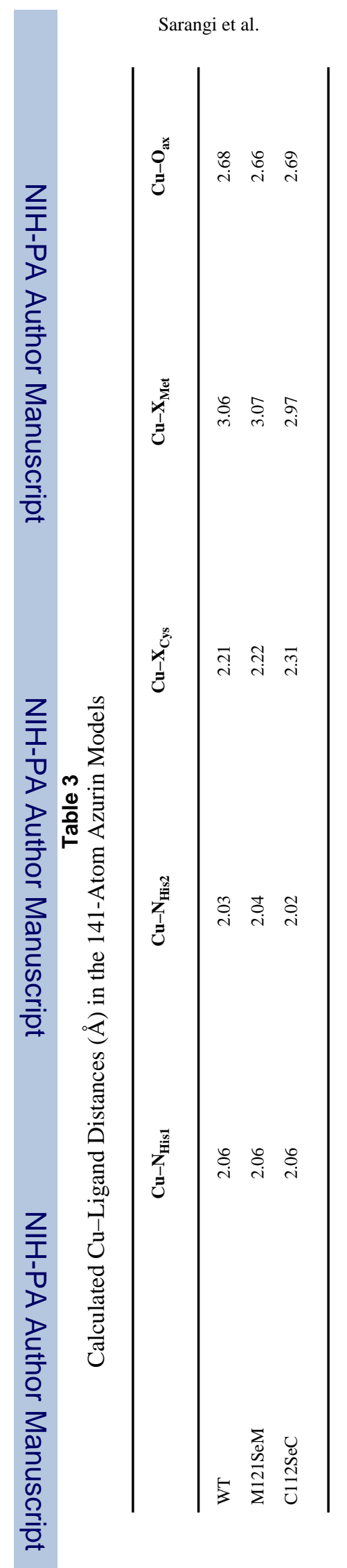

Page 28 


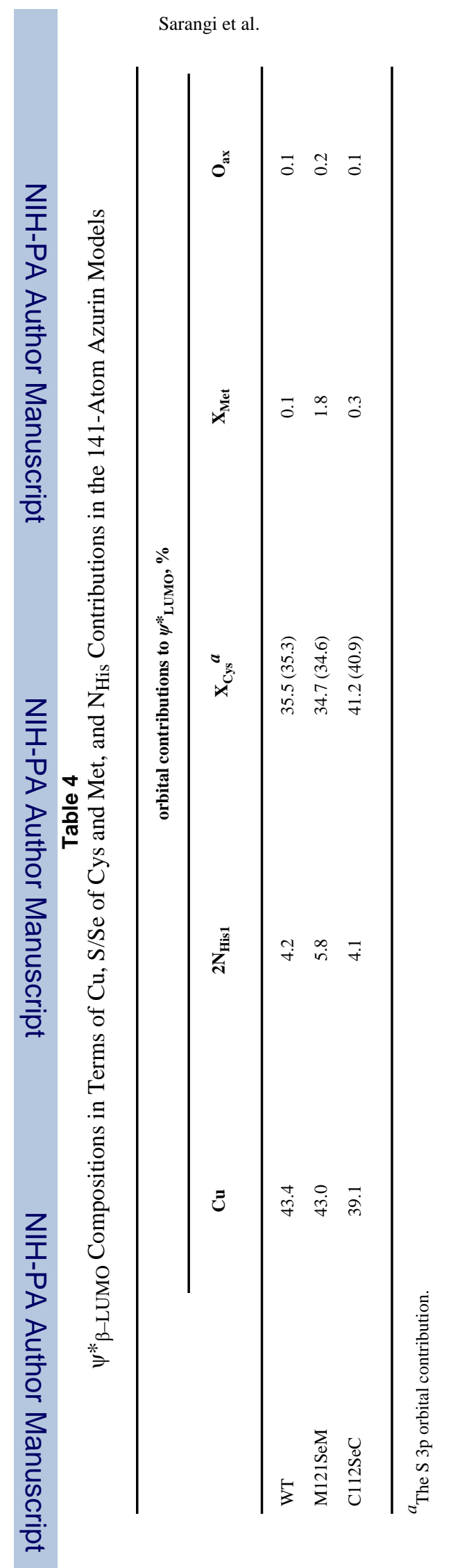

Page 29 


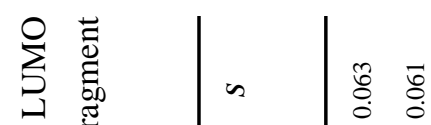

흔

of

כ

:

द्वे के

$0 \pm$

熍

ज苛

苛

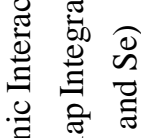

产 要

造 0

I

起 :

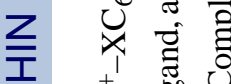

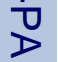

तิ

$>0$ 的望

无记

으 这

ख

के

음

하

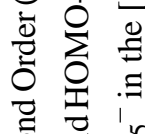

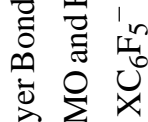

항

需

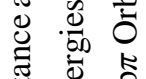

응

劳

范

क

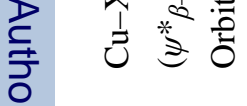

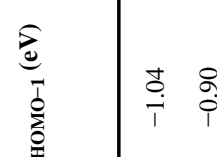

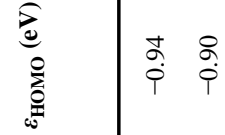

(a)

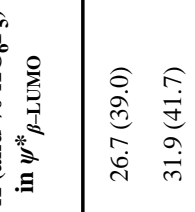

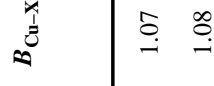

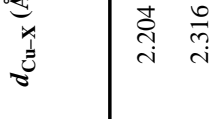

J Am Chem Soc. Author manuscript; available in PMC 2009 July 22. 